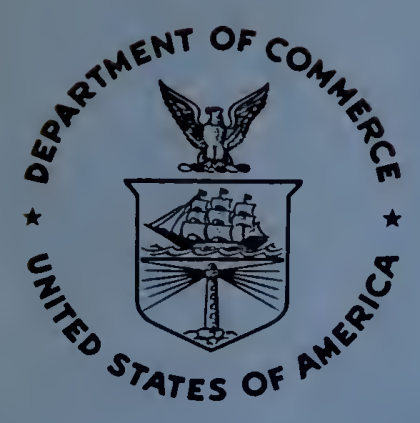

\title{
A Comprehensive Review of the Commercial Oyster Industries in the United States
}

Washington, D.C.

March 1977

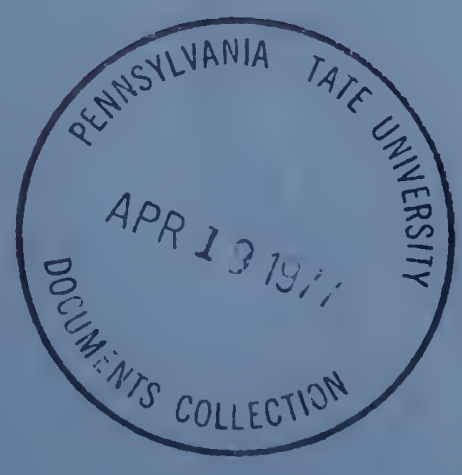





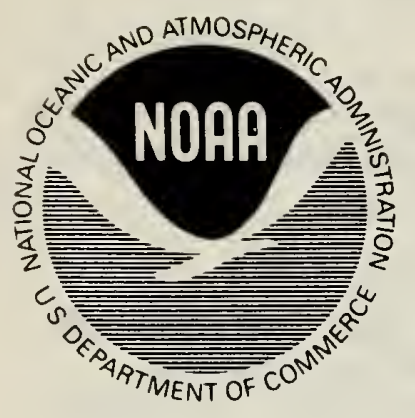

\section{A Comprehensive Review of the Commercial Oyster Industries in the United States}

Prepared by

Office of Fisheries Development

National Marine Fisheries Service

Washington, D.C.

March 1977

U.S. DEPARTMENT OF COMMERCE Juanita M. Kreps, Secretary National Oceanic and Atmospheric Administration Robert M. White, Administrator National Marine Fisheries Service Robert W. Schoning, Director 
The Office of Fisheries Development wishes to express its appreciation to the numerous National Marine Fisheries personnel who assisted in the development of this report.

David M. Dressel and E. Spencer Garrett served as Principal CoInvestigators. Vito Blomo, Thomas Carver, Charles Coss, Benjamin Drucker, Donald FitzGibbon, Daniel Goldmintz, James D. Meehan, Melvin Waters, and Donald Whitaker served as Contributing Authors. John Glude, National Marine Fisheries Service, and Rolf M. Nilsestuen, Environmental Science Information Center, helped review and edit the report.

More than 120 individuals from the oyster industry and from State and Federal agencies participated in the interviews and provided the thoughts, ideas, and suggestions that form the foundation for the material contained in this report.

For sale by the Superintendent of Documents, U.S. Government Printing Office

Washington, D.C. 20402 - Price $\$ 2.10$

Stack Number 003-020-00131-9 
ACKNOWLEDGEMENT . . . . . . . . . . . . . . . . . . . ii

I. EXECUTIVE SUMMARY. . . . . . . . . . . . . . . . . . . . . . . 1

II. INTRODUCTION . . . . . . . . . . . . . . . . . . . . 4

A. Background . . . . . . . . . . . . . . . . . . . . 4

1. Previous Studies of the Oyster Industry. . . . . . . 4

2. Present Study. . . . . . . . . . . . . . . 5

3. Approach . . . . . . . . . . . . . . . 5

B. Industry Status. . . . . . . . . . . . . . . . 5

1. East and Gulf Coast Industry . . . . . . . . . . 5

2. West Coast Industry. . . . . . . . . . . . . 6

3. The Industry as a Whole. . . . . . . . . . . 6

a. Harvesting Sector. . . . . . . . . . . . 6

b. Processing Sector. . . . . . . . . . . . 7

c. Eastern Oysters. . . . . . . . . . . . 8

d. West Coast Oysters................ 11

e. Imports. . . . . . . . . . . . . . . . . . 11

III. GROWING WATERS AND THE ENVIRONMENT . . . . . . . . . . . . . 12

A. Technical Issues . . . . . . . . . . . . . . . . 12

1. Natural Environmental Issues............ . 12

a. Natural Disasters. . . . . . . . . . . 12

b. Uncontrolled Runoff. . . . . . . . . . . . . 12

c. Red Tides. . . . . . . . . . . ..... 12

d. Biological Agents. . . . . .......... . 13

2. Manmade Conditions - Pollution . . . . . . . . . . 13

a. Industrial, Agricultural, and Domestic Wastes. . . 13

b. Physical Alterations . . . . . . . . . . 14

3. Defining "Suitable" Growing Waters . . . . . . . . . 14

a. Indicator Microorganisms . . . . . . . . . 15

b. Growing Water Standards. . . . . . . . . . 15

c. Chemical Standards . . . . . . . . . 15

B. Socio-Economic Issues. . . . . . . . . . . . . . 16

1. Competing Uses..................... 16

2. High Cost of Research and Service to Clean the Water . . 16

3. Net Benefits From Competing Uses . . . . . . . . . 18

4. Economic Criteria for Environmental Improvement. . . . . 19

5. Nature of Pollution from Competing Users . . . . . . . 19

a. Domestic . . . . . . . . . . . . . 19

b. Agriculture. . . . . . . . . . . . . 20

c. Industry .. . . . . . . . . . . . . . . 20

d. Recreation .. . . . . . . . . . . . 20

e. Urban Development. . . . . . . . . . . 20

6. Social Aspects... . . . . . . . . . . . 20

7. Recreation . . . . . . . . . . . . . . 21

8. Aesthetic Beauty . . . . . . . . . . . . . 21

C. Political Issues... . . . . . . . . . . . . . . 21

1. Competing Uses . . . . . . . . . . . . . . 22

a. Industry . . . . . . . . . . . . . . . 22

b. Urban Development. . . . . . . . . . . 22

c. Recreation.............. . 22 
2. Political Compromise . . . . . . . . . . . . 22

a. Watermen Lack Organization . . . . . . . . . 23

D. Institutional Issues . . . . . . . . . . . . . . . 23

1. Multijurisdictional Authorities. . . . . . . . . 23

E. Public Health Issues . . . . . . . . . . . . . . 23

1. Need for More Precise Correlation of Microbiological Standards With Public Health Significance. . . . . . 24

2. Multijurisdictional Authority. . . . . . . . . . 25

IV. RESOURCE AVAILABILITY. . . . . . . . . . . . . . . 26

A. Technical Issues . . . . . . . . . . . . . . 26

1. Existing Resources... . . . . . . . . . . . 26

a. Resource Assessment. . . . . . . . . . . . 26

b. Water Quality Standards. . . . . . . . . . 26

c. Relaying and Depuration. . . . . . . . . . 27

d. Canning. . . . . . . . . . . . . . . 27

e. Increasing Public Oyster Resources . . . . . . . 27

f. Predator or Competitor Control . . . . . . . . 27

g. Aquaculture. . . . . . . . . . . . . . 28

h. Space in Suitable Environments . . . . . . . 29

i. Disease and Predator Control . . . . . . . . . 29

j. Inconsistent Supply. . . . . . . . . . . . . 29

k. Genetic Improvement and Selective Breeding . . . . 29

1. Seed Supply. . . . . . . . . . . . 29

B. Socio-Economic Issues. . . . . . . . . . . . . . . 30

1. Closed Areas . . . . . . . . . . . . . . 30

2. Seed/Cultch Planting.............. . 30

3. Public Versus Private Fishery. . . . . . . . . . 31

4. Aquaculture. . . . . . . . . . . . . . 31

C. Political Issues .. . . . . . . . . . . . . . 31

1. Competing Uses of Growing Waters . . . . . . . . . . 31

a. Clammers Versus Oystermen. . . . . . . . . . 31

b. Public Versus Leased Oyster Bottoms. . . . . . . 31

2. Cost/Benefit of Habitat and Stock Improvement. . . . . 32

3. Multijurisdictional Authorities. . . . . . . . . . 32

D. Public Health Issues . . . . . . . . . . . . . . 33

1. Dispute on Significance of Indicator Microorganisms. . . 33

2. Need for Chemical Standards. . . . . . . . . . 33

3. Remote Monitoring. . . . . . . . . . . . . . . 33

V. HARVESTING . . . . . . . . . . . . . . . . . . . 35

A. Technical Issues . . . . . . . . . . . . . 35

1. Gear Development . . . . . . . . . . . . . 35

2. Quality Factors. . . . . . . . . . . . 35

B. Socio-Economic Issues. . . . . . . . . . . . . 36

1. Prices . . . . . . . . . . . . . . 36

2. Gear . . . . . . . . . . . . . . 36

3. Regulations. . . . . . . . . . . . . 36

4. Labor Force. . . . . . . . . . . . . . . 37

a. Job Esteem . . . . . . . . . . . . . 37

b. Alternative Employment Opportunities . . . . . . 38

5. Financial Assistance . . . . . . . . . . . . . 38 
C. Political Issues . . . . . . . . . . . . . . . 39

1. Lack of Industry Input Into Public Policy Decisions. . 39

a. Harvesting Quotas. . . . . . . . . . . 39

b. Conservation Quotas. . . . . . . . . . 39

c. Marketing Quotas . . . . . . . . . . . 39

d. Social Purposes. . . . . . . . . . . . . . 40

e. Harvesting Gear Restrictions . . . . . . . . . 40

2. Bootlegging. . . . . . . . . . . . . . . 40

3. Planning Industry Stability. . . . . . . . . . . 41

a. Over-Regulation. . . . . . . . . . . . 41

b. Financial Support. . . . . . . . . . . 41

D. Institutional Issues. . . . . . . . . . . . . 42

1. Public Assistance Opportunity Competition. . . . . . . 42

2. Multijurisdictional Authority. . . . . . . . . . 42

E. Public Health Issues . . . . . . . . . . . . . . . 42

1. Bootlegging. . . . . . . . . . . . . . . 42

2. Vessel and Truck Sanitation Standards. . . . . . . 44

VI. PROCESSING . . . . . . . . . . . . . . . . . . 45

A. Technical Issues .. . . . . . . . . . . . . 45

1. Lack of Mechanization. . . . . . . . . . . . 45

2. Limited Product Forms. . . . . . . . . . . . . 45

3. Need for a Practicable Quality Standard. . . . . . . 45

B. Socio-Economic Issues. . . . . . . . . . . . . . 46

1. Labor. . . . . . . . . . . . . . . . . 46

2. Transportation .............. . . 4 46

3. Foreign Competition. . . . . . . . . . . . 46

4. Financial Credit... . . . . . . . . . . 46

5. Product Liability. . . . . . . . . . . . . 46

C. Political Issues ... . . . . . . . . . . . . 47

1. Competing Use for Land Space (Zoning). . . . . . . . 47

2. Lack of Industry Input Into Public Policy Decisions. . 47

D. Institutional Issues . . . . . . . . . . . . . 47

1. Multijurisdictional Authority. . . . . . . . . . . 47

a. Plant Construction, Maintenance, and Safety. . . . 47

b. Product Safety... . . . . . . . . . . 48

c. Administrative and Record Keeping. . . . . . . 48

d. State/Overseer/Coordination. . . . . . . . . 48

e. Reciprocal Agreements. . . . . . . . . . . 48

f. Multipurpose Record Forms. . . . . . . . . . 48

E. Public Health Issues . . . . . . . . . . . . . . 49

1. Dispute Over Significance of Indicator Microorganisms. . 49

2. Relationship Between Heat Processing and Pathogen

Destruction for Non-Commercialized Sterilized

Products Such as Pasteurization. . . . . . . . . . 49

3. Need for Practical Lot Coding and Segregation to

Trace Oysters to Growing Waters. . . . . . . . . . . 49

4. Improved Coordination of Research and Inspection Methods 49

5. Increased Inspection Training. . . . . . . . . . . 50

VII. MARKETING AND CONSUMPTION. . . . . . . . . . . . . . 51

A. Technical Issues . . . . . . . . . . . . . . 51 
1. Insufficient Product Development . . . . . . . . . 51

2. Retail Quality Standards . . . . . . . . . . . 51

3. Consumer Education . . . . . . . . . . . . 51

4. Retailer Training. . . . . . . . . . . . . . 51

B. Socio-Economic Issues. . . . . . . . . . . . . . . 51

1. Marketing. . . . . . . . . . . . . . . 52

C. Political Issues . . . . . . . . . . . . . . 52

D. Institutional Issues . . . . . . . . . . . . . . 53

1. Consumer Education . . . . . . . . . . . . . 53

E. Public Health Issues . . . . . . . . . . . . . . 53

1. Retail Standards . . . . . . . . . . . . 53

2. Stringent Raw Material Requirements for Canned Oysters . 53

VIII. FINDINGS AND CONCLUSIONS . . . . . . . . . . . . . . . 54

A. Findings . . . . . . . . . . . . . . . . . 54

1. Principal Issues . . . . . . . . . . . . . . . 54

a. Competition for Use of Growing Waters and Adjacent

Lands. . . . . . . . . . . . . . . . . 54

b. Multijurisdictional Authorities and Regulations. . 55

c. Decreasing Resource Base . . . . . . . . . 55

d. Industry Revitalization. . . . . . . . . . 56

e. Social Concerns. . . . . . . . . . . . . 56

f. Industry Has Little Influence on Public Decision

Making . . . . . . . . . . . . . . 57

g. Precision of Microbiological and Chemical Standards Currently Employed in Classifying Suitable Growing Waters and Final Products. . . . . . . . . . 57

h. Research and Services Coordination . . . . . . 58

B. Conclusions. . . . . . . . . . . . . . . . . 58

1. Industry Revitalization Needs. . . . . . . . . . 58

a. Pollution Abatement. . . . . . . . . . . . . 58

b. Expanding Natural Production . . . . . . . . 59

c. Aquaculture. . . . . . . . . . . . . 59

d. Mechanization. . . . . . . . . . . . 59

e. New Product Development. . . . . . . . . . 59

f. Advertising and Marketing. . . . . . . . . . 60

g. Financial Assistance . . . . . . . . . . . . 60

h. Multijurisdictional Authorities and Regulations. . . 60

i. Research Coordination. . . . . . . . . . . 60

j. Social Concerns. . . . . . . . . . . . . 60

2. Leadership Concerns. . . . . . . . . . . . 61 


\section{EXECUTIVE SUMMARY}

The oyster industry is an important source of food supply for the nation and contributes substantially to the economic wealth of the country. The report indicates that:

1. Domestic landings of oysters have declined from 90 million pounds (meat weight) to about 54 million pounds in the 1970's. Among the reasons for the decline are overfishing, natural disasters, water pollution, and, possibly, over-regulation.

2. More U.S. plants produce oyster products than any other single fishery product. Thirty percent of the 1,476 fishery processing plants in the 48 contiguous states produced oyster products in 1975. Most of the plants are located on the East and Gulf Coasts and in the Pacific Northwest.

3. The oyster industry is one of the top five fisheries in terms of employment. In 1973, 11,748 people were employed at the harvesting level, including about 8,700 full-time fishermen. Employment at the processing level was 5,556 persons in 1975, but is decreasing.

The industry is faced with a host of problems such as resource depletion, competition for growing waters, and new regulations, most of which are external in nature.

A small task group surveyed the industry and interviewed members of the industry, State Departments of Conservation, and Public Health and Federal agencies to delineate the issues and identify requirements for their resolution. The findings and major issues identified from these interviews are discussed in the report.

A summary of the eight dominant issues follows:

$$
\begin{gathered}
\text { Competition for Use of Growing } \\
\text { Waters and Adjacent Lands }
\end{gathered}
$$

Competition for use of the coastal zone is a major issue confronting the oyster industry. Due to the industry's small size, lack of public awareness, and imprecisions of economic cost/benefit studies, the industry often is assigned a low priority when competing for coastal zone allocations.

\section{Multijurisdictional Authorities and Regulations}

The industry is regulated by many Federal, State, and local authorities, each having its own record keeping requirements. Major Federal regulatory and inspection responsibilities are shared by the Food and Drug Administration, the Environmental Protection Agency, the National Marine Fisheries Service, and 
to a lesser extent, the Occupational Safety and Health Adninistration, and the U.S. Army Corps of Engineers. Major State agencies in Public Health Conservation and Water Pollution Control are also involved.

Additionally, other governmental bodies impact the industry, including local county agricultural committees and urban drainage authorities, local public works bodies, regional and multistate river basin commissions, and zoning authorities.

\section{Decreasing Resource}

The dramatic decline of U.S. oyster production is laid to three causes: (1) overharvesting in earlier years, (2) natural causes (disasters, diseases, and predators), and (3) man's depredations of the environment. The nation's oyster harvesting acreage is shrinking at an annual rate of 0.6 percent, principally because of closings due to water pollution. Physical alterations of the environment affect the currents and salinities, and pollution alters the productivity of the remaining beds by degrading the quality of water suitable for larvae and juveniles, thus interfering with the natural process of reproduction.

\section{Industry Revitalization}

With the exception of a few large commercial operations, the character of the oyster industry has remained virtually unchanged for generations. Harvesting is done largely by individuals or family groups, of en with inefficient gear. State and local harvesting quotas are established on public bottoms to conserve the resource and for social purposes. These restrictions are based largely on gear efficiencies, the number of harvesters, the resource, processing plant capabilities, and tradition.

Many processing facilities are small, family-owned, laborintensive, and marginally-profitable. They are faced with fluctuating supplies of oysters, decreasing labor base, increasing costs, and new regulations and record keeping which decrease production efficiencies and further raise operating costs. The marketing of oysters has been confined to the fresh, canned, and frozen items, and there has been little new product development. Oyster prices are not keeping pace with inflation.

\section{Social Concerns}

Oystering is one of the last holdouts of rugged individualism in America. The life is hard, but people continue to follow it because of the tradition that belongs to the trade, the feeling of freedom and independence, and the enjoyment 
of boats, water, and the outdoor life. The clean environment needed for the shellfish industry provides a pleasing aesthetic surrounding for those living and working in these areas. Pristine bays and estuarine waters make these areas desirable, as is reflected in higher real estate values. The decline of the oyster industry signals a change in all aspects related to the water.

\section{Industry Has Little Influence on Public Decision Making}

The total industry is composed of small units and of ten does not possess the capital to promote its image or to adequately present its views midst a complex array of external problems. Although there are associations representing harvesters and processors from the local to the national level, almost without exception, individuals in the industry constantly voiced the complaint that they have little influence with public policy makers.

\section{Precision of Microbiological and Chemical Standards} Currently Employed in Classifying Suitable Growing Waters and Final Products

The current microbiological limits, based on a study on clams in the early 1940's, need further study and refinement which may prove them to be overly discriminating. Additionally, improvements can be achieved in the manner in which chemical standards are developed.

\section{Research and Services Coordination}

There appears to be a lack of a specifically defined and coordinated systematic mission- or goal-oriented program of research and/or services to resolve many issues confronting the U.S. oyster industry.

The report concludes, based on these findings, that the industry is in drastic need of revitalization. Cooperation and joint leadership, through a small dynamic Government/Industry Commission or task force, are needed for the industry to become more economically viable. The report identifies specific needs in the areas of pollution abatement, expanding natural production, aquaculture, mechanization, new product development, marketing, financial assistance, multijurisdictional authorities and regulations, research and services coordination, social concerns, and leadership roles. 


\section{INTRODUCTION}

This review of the oyster industry provides technical background for the U.S. Department of Commerce's response to the requirements of Section 16 (2) (1) of the Coastal Zone Management Act Amendments of 1976, signed into law on July 26, 1976. The aforementioned Section, popularly known as the Bauman Amendment, among other things, directs the Secretary of Commerce to:

"...undertake a comprehensive review of all aspects of the molluscan shellfish industry, including, but not limited to, the harvesting, processing, and transporation of such shellfish and, ...not later than April 30, 1977, submit a report to the Congress of the findings comments, and recommendations (if any) which result from such review and evaluation..."

This review identifies the principal technical, socio-eocnomic, institutional, political, and public health issues associated with the growing harvesting, processing, and marketing of oyster products, and identifies requirements for their resolution. It should be noted that during the deliberations on the proposed Bauman Amendment, at one time, there was a requirement for the Secretary of Commerce to make an effectiveness study of proposed changes to the National Shellfish Sanitation Program by the U.S. Food and Drug Administration. This requirement, however, was deleted prior to agreement in Conference Committee, and this review does not specifically address the proposed National Shellfish Safety Program.

\section{A. Background}

The shellfish industry is beset with severe economic stresses such as a declining resource base, a declining labor base, increased labor costs, declining demand, inflation, and restrictive regulations in general. Furthermore, the wholesale price of the product is generally not keeping up with the increase in the cost of living.

\section{Previous Studies of the Oyster Industry}

.. Numerous studies of the oyster industry have been conducted. For the most part, such studies have been limited to specific aspects of a portion of the industry or limited research to answer specific questions on the industry as a whole.

Research and services supported by the National Oceanic and Atmospheric Administration under the Sea Grant Program and P.L. 88-309 program administered by the National Marine Fisheries Service, or its predecessor agency has cost slightly in excess of $\$ 14$ million for the decade 1965-75, as follows:

Growing waters/environment

Resource availability

Harvesting and transportation

Processing

Marketing and consumption

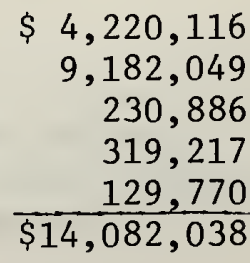

Tota1 
In addition, research on growth, disease and predators, and aquaculture methods at laboratories of the National Marine Fisheries Service, or its predecessor agency, (for the decade 1966-76) cost about \$4,578,300. The Food and Drug Administration and various individual oyster-producing states have also supported continuing programs related to the oyster industry.

\section{Present Study}

This comprehensive review was undertaken to systematically define the numerous issues facing the oyster industry and requirements for their resolution.

A matrix format was used to provide full subject coverage and to identify dominant issues and problems interrelations. The chosen format, shown below, divides the industry into five major categories and then examines each in terms of five potential problem groupings. Repetition is by design and serves to pinpoint major issues needing resolution.

\section{MATRIX}

\section{Subject Area}

Growing Waters and the Environment

Resource Availabity

Harvesting

Processing

Marketing and Consumption

\section{Issues}

Technical

Socio-Economic

Political

Institutional

Public Health

\section{Approach}

A small, interdisciplined task group surveyed the oyster industry and interviewed industry members, trade associations, members of State Public Health and Conservations agencies, large institutional purchasers of oysters and oyster products, and personnel of other Federal agencies. Because of time limitations, interviews were conducted in the following states: Alabama, Louisiana, Maryland, Mississippi, New York, Oregon, Virginia, and Washington, which are representative of the industry.

\section{B. Industry Status}

\section{East and Gulf Coast Industry}

The oyster industry on the east and gulf coasts harvests the American or Eastern oyster, Crassostrea virginica. This species ranges from Canada to Mexico; and Maryland, Louisiana, Virginia, and Florida are the leading producers of Eastern oysters. The oyster thrives in protected and nutrient laden estuaries and is tolerant of a wide range of salinities. Throughout its range, the growth rate is temperature dependent and includes a considerable variation. In Southern and Gulf States, market size oysters can be produced in two years, while from the Chesapeake Bay and north, it takes four to five years to produce a market size oyster. 
Most of the harvest is dependent on natural recruitment. Naturallyproduced seed oysters from densely populated estuaries are transferred and planted on both public and private oyster growing areas. The James River in Virginia is the largest seed oyster-producing area in the world, supplying 70 percent of the oysters planted in Virginia. James River seed oysters are also sold to neighboring states. The Connecticut estuaries are important seed producers which supply most of the seed used by Long Island oyster farms. Environmental conditions and water quality are critical to oyster production and larvae development, and, therefore, it is essential that seed-producing areas be adequately protected. Hatchery operations, while of increasing importance, supply a relatively small percentage of the total seed production.

Aquaculture is important to the national production of oysters. In 1974, aquaculture activities accounted for approximately 40 percent of the U.S. oyster harvest. The term aquaculture includes a wide array of activities from the simple transfer of seed oysters to growing areas to the most sophisticated closed systems. Aquaculture is helping to replenish and stabilize wild populations which have declined drastically during the last 70 years from pollution, natural disasters, and disease.

Harvesting techniques vary, and, to conserve the resource, are frequently limited to inefficient labor-intensive methods on public grounds. Private growers, however, can often use efficient escalator and hydraulic dredge boats capable of harvesting up to 2,000 bushels per day with a 2-man crew. In addition, private oyster farmers can harvest their beds throughout the year; public areas are frequently closed 4 to 5 months of the year to conserve the resource.

\section{West Coast Industry}

West coast oyster production is centered on two species: the Western native oyster, Ostrea lurida, and the large Pacific oyster, Crassostrea gigas. Early attempts to introduce the American oyster, Crassostrea virginica, were initially successful at the turn of the century, but unexplained massive mortalities have virtually eliminated the species. West coast production is almost entirely by aquaculture on private leased bottoms with Washington the major producer; Oregon and California also contribute. Most seed oysters are still imported from Japan; a practice which started in the 1920 's. There is, however, an increasing reliance on hatchery seed and some limited natural set occurs.

Harvesting techniques vary and are dependent to a large extent on the bottom and tidal amplitude. Oysters can be harvested by hand at low tide on exposed bars. Large hydraulic dredges are used in deeper waters.

\section{The Industry as a Whole}

\section{a. Harvesting Sector}

In 1973 , there were 11,748 people harvesting oysters including about 8,700 full-time fishermen. By region, 5,887 were employed in Chesapeake Bay area, and in the Gulf of Mexico region, 3,295. The total number of oyster 
fishermen has been decreasing from 14,000 in the 1950 's, probably because of declining resource.

Domestic landings of oysters have been declining for decades. For example, in 1929, 90 million pounds (meat weight) were landed, and in the $1970^{\prime} \mathrm{s}$, the average annual landings stand at 54 million pounds. Eastern oysters landed all along the east coast account for most of the decrease in the harvest. There are several reasons for the decline, including (1) overfishing, (2) natural disasters, (3) oyster diseases (such as MSX and Dermocystidium), and (4) the closure of waters because of pollution.

The value of oyster landings has increased despite the decreased landings, thus indicating a rise in exvessel prices. The harvest value in 1967 was $\$ 32.2$ million compared to $\$ 45.6$ million in 1975 . When the effects of inflation are removed from the value of landings, however, exvessel prices in the 1968-73 period actually declined compared to 1967 , and then increased by 14 percent in 1975. This development can be compared with the prices paid to fishermen of all edible fish and shellfish, which more than doubled since 1967. In the 1971-75 period, the average annual harvest from public grounds was 31.6 million pounds (meat weight) and 20.9 million pounds from private grounds. The public and private acreage in 1975 was 817,057 and 442,088 acres, respectively.

\section{b. Processing Sector}

Most oysters are sold as fresh and frozen shucked, steamed, or canned oyster products, including specialty products. The sale of oysters in the shell for raw consumption, although limited, has significant regional importance. Almost all of the oysters produced by oyster farms in Long Island are sold for the raw bar trade, and in Louisiana, private beds are harvested year 'round to meet the high raw bar demands in New Orleans. By contrast, native Western and Pacific coast oysters are not normally eaten raw.

More plants produce oyster products than any other single marine species in the United States. Oysters were processed in about 30 percent of the 1,476 processing plants in the United States (excluding Alaska and Hawaii). The total preliminary value of production at the plant level in 1975 was $\$ 81$ million plus $\$ 5.8$ million for crushed shell products. The final retail value of these products was at least $\$ 121$ million, assuming a conservative 50 percent markup. It more likely was closer to \$156 million.

Employment in the processing sector stood at 5,556 in 1975, down from 6,200 workers in 1971. By region, in 1975, the Chesapeake Bay and the Gulf of Mexico areas again have the highest number of employees, 2,519 and 1,891 respectively. The oyster processing industry provides mainly seasonal employment. The number of workers is half or less during the summer as during the peak fall and winter months. The industry is still labor-intensive, and without many of the technological developments found in other seafood and processing industries.

The oyster processing industry can be conveniently divided into the Eastern oyster industry (including the Gulf of Mexico) and the west coast 
industry. The other most convenient division is between fresh shucked and oysters and canned oysters.

1975 Sales of Oyster Products

(F.O.B. plant)

\section{$\underline{\text { Eastern }}$}

\section{$\underline{\text { Sales }}$}

Fresh shucked or steamed

Canned

Breaded

Specialties, fresh or frozen

Specialties, canned

$\underline{\text { Pacific }}$

$$
\begin{array}{r}
\$ 59,916,695 \\
4,064,946 \\
5,389,104 \\
362,883 \\
2,898,837 \\
\hline \$ 72,632,465
\end{array}
$$

Fresh shucked

$\$ 5,436,332$

109,425

Breaded

Specialties, canned

$\frac{2,505,249}{\$ 8,051,006}$

\section{Byproducts}

Crushed shell and lime

$\underline{\$ 5,846,584}$

Grand tota1

$\$ 86,530,055$

\section{c. Eastern Oysters}

By far the largest number of plants are engaged in processing eastern oysters. Of the 448 plants producing oyster products, 398 process eastern oysters. Fresh shucked oysters dominate production. Of the 398 plants processing eastern oysters, 345 produced fresh shucked products. The remaining plants produced the following: steamed oysters, 3; breaded oysters, 31; frozen shucked oysters, 3; specialties, 4; canned oysters (including specialties), 13; and shell products, 5. Some plants may do one or more stages of processing, such as steaming and shucking; therefore, because of duplication, this total does not add to 398 .

The processing sector is composed primarily of a large number of sma11, family-owned businesses. Twenty-four percent of the plants have sales; of $\$ 25,000$ or less, which means their annual production runs about 2,600 to 2,800 gallons of oysters. Over a 200-day season, these plants would average about 13 gallons or less per day. The following table compares Eastern oyster processing plants relative to sales volume. 
Structure of Plants Producing

Fresh and Frozen Eastern Oysters

1975 Sales

Less than $\$ 25,000$

$\$ 25,000$ to $\$ 49,999$

$\$ 50,000$ to $\$ 99,999$

$\$ 100,000$ to $\$ 199,999$

$\$ 200,000$ to $\$ 299,999$

$\$ 300,000$ to $\$ 399,999$

$\$ 400,000$ to $\$ 499,999$

$\$ 500,000$ to $\$ 599,999$

$\$ 600,000$ to $\$ 699,999$

Over $\$ 700,000$
Number of plants

91

50

57

83

38

18

12

14

3

$\frac{16}{382}$
Percent of plants

23.8

13.1

14.9

21.7

10.0

4.7

3.1

3.7

.8

$\frac{4.2}{100.0}$

It is a well-known fact that the seafood processing industry is composed of a great number of small plants and relatively few large plants. The following table compares Eastern oyster plants to all seafood processors in the United States.

\section{Sales}

Less than $\$ 100,000$

$\$ 100,000$ to $\$ 500,000$

$\$ 500,000$ to $\$ 1,000,000$

Over $\$ 1,000,000$

\section{Eastern oysters} (\% of plants)
All seafood processors (\% of plants)

\begin{tabular}{rr}
51.9 & 33.6 \\
39.5 & 34.8 \\
6.8 & 11.2 \\
1.8 & 20.4 \\
\hline 100.0 & 100.0
\end{tabular}

Eastern oyster processors tend to deal almost exclusively in oysters. Over 70 percent of the plants produce nothing but oyster products. Over 76 percent of the plants have 80 percent or more of their production in oysters.

Eastern Fresh and Frozen Plant Oyster Production as a Percent of Total Seafood Plant Production

(1975)

\section{Percent oysters}

$100 \%$ oyster products

$91 \%$ or more oyster products

$81-90 \%$ oyster products

$71-80 \%$ oyster products

$61-70 \%$ oyster products

$51-60 \%$ oyster products

Less than $50 \%$ oyster products

\section{Number of plants Percent of plants}

269

12

10

5

3

6

$\frac{77}{382}$
70.4

3.1

2.6

1.3

.8

1.6

$\frac{20.2}{100.0}$ 
The species most often produced in conjunction with oysters is blue crab, followed by shrimp, clams, and bay scallops. The tendency to process more than one species is much less prevalent than in seafood plants in general, as shown in the following table.

Other Products Produced in Plants With Eastern Oyster Fresh and Frozen Production

(1975)

\section{$\underline{\text { Species }}$}

Blue crab

Shrimp

Soft clams

Hard clams

Bay scallops

Mullet

Flounder

Catfish

Crawfish

Surf clams

Sea trout

Red snapper

Sea scallops

Conchs

Calico scallops

Unclassified for food fish

\section{Number of plants}

56

41

14

9

10

5

16

1

1

7

6

1

18

1

4

13

The canning of eastern oysters presents an entirely different industry structure from fresh shucked oysters. While the fresh industry stretches from Maine to Texas, the canned pack of natural (canned in broth without condiments) Eastern oysters is confined primarily to the deep South (Louisiana, 5 plants; Mississippi, 5 plants; South Carolina, 2 plants). Canned specialties are produced in New Jersey, 1 plant; South Carolina, 2 plants; and Louisiana, 1 plant. In the South, oyster canning is more likely to be a portion of the total production of a plant which produces other canned products.

The structure of the natural oyster canning industry is as follows:

$\underline{\text { Sales }}$

Less than $\$ 100,000$

$\$ 100,000$ to $\$ 250,000$

$\$ 250,000$ to $\$ 500,000$

Over $\$ 500,000$
Number of plants

4
2
2
4

of the 12 southern plants canning natural oysters in 1975, only 3 produced nothing but canned oysters; shrimp was the primary product canned in the other 9 plants. In only two cases did oysters comprise more than half the production. Two of the 9 plants also canned blue crab, and 2 canned other specialty items. 
Production of natural canned oysters totaled 343,084 standard cases ( 24 cans of 4-2/3 oz.) in southern plants in 1975.

\section{d. West Coast Oysters}

The structure of the west coast industry is very nearly like that of the east coast--many small plants and a few large ones.

Structure of Plants Producing

Fresh and Frozen West Coast Oysters

1975 Sales

Less than $\$ 25,000$

$\$ 25,000$ to $\$ 49,999$

$\$ 50,000$ to $\$ 99,999$

$\$ 100,000$ to $\$ 199,999$

Over $\$ 200,000$
Number of plants Percent of Plants

\begin{tabular}{rr}
21 & 47.7 \\
3 & 6.8 \\
8 & 18.2 \\
5 & 11.4 \\
7 & 15.9 \\
\hline 44 & 100.0
\end{tabular}

Of the 44 oyster plants on the west coast, 39 produce only oysters. In the 5 plants that process other products, 2 plants have over 90 percent of their production in oysters, 2 plants have over 70 percent of their production in oysters, and 1 plant produced a small amount of oyster products. One plant also produced shell products.

No west coast plant canned oyster meats in 1975, although 7 plants did can specialty products that year such as stews and smoked products. Low cost imports have replaced west coast canning of oysters in broth.

\section{e. Imports}

Imported oyster products come in three forms: canned, frozen, and fresh shucked. Limited quantities of fresh-shucked oysters are imported mainly from Canada.

Canned imports are cooked sterile products available as bisques, soups, stews, smoked oysters or oysters in their own juice. In 1975, 76 percent of imported oysters were canned. As almost all canned imports are from Japan and Korea (Pacific oysters), they affect the ability of Pacific and Gulf Coast oyster canners to compete due to reported lower production costs. Following a somewhat steady growth in the importation of canned oyster products, there was an increase of over 200 percent in 1972. Overa11, oyster imports have tripled since 1975. Imported canned oyster products have generally replaced domestic canning with total supplies of oysters in the U.S. fluctuating between 64 and 79 million pounds since 1963 (averaging 70 million pounds meat weight). 
2.2.1.5. Biotoxins. Paralytic shellfish poisoning (PSP) is due to consumption or molluscan shellfish that have accumulated toxic dinoflagellates. Incidents of PSP have been reported from the Pacific and Alaskan Coasts, northern New England and Florida. Massive blooms of toxic and non-toxic dinoflagellates often color sea water and blooms are sometimes referred to as red-tides. Toxic dinoflagellate blooms are a public health hazard and also an industry problem. The industry problem is associated with prolonged and adverse publicity concerning red-tides and this affects the marketability of clams and most seafood (Marine Research, Inc., 1976). On the east coast, the first (PSP) harvesting area closures were made in Maine in 1958 (Dow, 1976). Before 1972, the bloom causing toxic dinoflagellate, Gonyaulax tamarensis, was reported only in waters of northern Maine. In 1972, a toxic red-tide did develop in other New England waters which extended as far south as Cape Cod. Hard clam production north of Cape Cod is insignificant and the major hard clam producing areas south of the Cape were unaffected by the bloom, but adverse publicity hindered the sale of hard clams and most seafood (Marine Research, Inc., 1976).

Since 1972, all New England hard clam producing states have established monitoring programs to detect the presence of toxic dinoflagellates. The Pacific coastal states and Alaska have long had similar monitoring programs.

Dinoflagellate blooms also occur in Florida primarily along the Gulf coast. The dinoflagellate that is responsible for red-tides in Florida is $\mathrm{G}$. brevis and not considered to be as toxic to humans as northern dinoflagellates.

\subsubsection{Climatic Problems}

Climate and weather are responsible for a number of hard clam industry problems. Heavy rainfall over extended periods of time can overload sewage treatment facilities and the drainage capacity of entire watersheds. Severe storms sometime deposit hard clams on beaches or smother resources.

\subsection{Resource Availability}

\subsubsection{Biological Problems}

Fluctuations in total United States hard clam landings have been attributed to economic as well as biological causes. Short term fluctuations are minimal because several age groups are included in the stocks. All States that commercially harvest hard clams report variations in natural abundance. The general life history of hard clams is understood. The minimal food requirements of larval, juvenile, and adult hard clams is generally known. The major predators, and the life history stages of clams at which these predators have the most impact, are reasonably well known (MacKenzie, 1976). The manner in which all this information interacts in the natural environment and causes fluctuations in hard clam abundance is not known. 
2.3.1.1. Brood stocks. An adequate brood stock, capable of maintaining a fishery resource at full biological productivity, is one of the most important objectives of fishery research and management (McHugh, 1976). Because hard clam resources fluctuate so much from "natural causes," basic'brood stock information is difficult to obtain.

Large brood stocks are present in areas that are closed to harvesting for public health reasons. In fact, the clam populations in most closed areas are significantly larger than clam populations in open harvesting areas. In many areas where heavy fishing pressure occurs, the larger chowder size hard clams are not harvested because the larger clams, especially Mercenaria sp., have had little or no market value until recently.

2.3.1.2. Recruitment. Low level recruitment is generally attributed to environmental conditions that adversely affect the successful spawning and subsequent survival and growth of larval and juvenile clams. Reduced recruitment is also attributed to overharvesting that reduces total clam populations to levels that are incapable of significant reproduction.

Most hard clam harvesting States report a low level recruitment of juvenile clams in areas that are harvested regularly. High level recruitment occurs occasionally, but when it does occur, one successful year class can sustain a sizable commercial fishery for a number of years.

Hatchery techniques for the production of large volumes of juvenile hard clams are well established (Loosanoff and Davis, 1963). Several State universities and clam industry companies are currently engaged in research projects aimed at developing inexpensive methods of rearing large quantities of juvenile hard clams. Juvenile hard clams must be protected from predation for one or more years until they attain a size that affords protection from major predators (Castagna, 1970).

2.3.1.3. Predation and disease. Mackenzie (1976) identifies the principal invertebrate predators of hard clams (Mercenaria sp.) as oyster drills (Urosalpinx cinerea and Eupleura caudata), moon snails (Polinices duplicata and Lunatia heros), whelks or conchs (Busycon canaliculatum and B. carlca), crabs (Neopanope sayi, Cancer irroratus and Callinects sapidus), and the sea star (Asterias forbesi). Puffer fish, drum fish, skates, rays, and diving ducks also feed on hard clams. Predation rates vary and the smallest clams are most vulnerable. Eventually, as hard clams increase in size, they become less vulnerable to most predators except blue crabs, whelks, moon snails, drum fish and rays.

Other than Chlamydia (otto, pers. comm.) no specific hard clam diseases have been reported. Several mass mortalities of hard clams have occurred, but causal agents have not been identified. Bacterial disease has cause mortality of Mercenaria larvae in the laboratory (Tubiash, 1965). 


\subsubsection{Resource Management Problems}

It is extremely difficult to achieve effective management control over any natural marine resource. Marine resource management problems are considerably increased when the resource is essentially owned by the State or public and when the resource is or has been subjected to continuous commercial and/or recreational harvesting. In States that have designated subaqueous land to molluscan shellfisheries, clam harvesting grounds have usually been the area left after natural oyster beds and leased oyster grounds have been designated.

Hard clam resource management regulations and existing laws pertaining to the utilization of hard clam resources in the major hard clam producing States have generally favored commercial utilization of the resource. New resource regulations are written with the consent of the harvesting industry (Cole, 1976) and in many cases, the industry existed prior to the establishment of resource management agencies.

There is also split jurisdictional problems within States, especially in the New York and New England areas where the clam resources are the property of local towns or communities. When the resource is locally owned, the towns can and do establish their own regulation which may be in conflict with State regulations. There are also jurisdictional problems with subareas that have been legally leased to individuals.

In New York, the regulation of hard clam harvesting is divided among town, county, State, and several federal agencies.

2.3.2.1. Stock assessment. In order to develop a resource management model, five basic types of information are essential: 1) The magnitude of the standing crop; 2) rate of renewal by growth; 3) rate of renewal by recruitment; 4) rate of removal by natural causes; and 5) rate of removal by harvesting (McHugh, 1976). The agencies responsible for managing hard clam resources generally lack such basic information. No consultants have reported Maximum Sustainable Yields (MSY's) for hard clam resources and it is doubtful if any of this information exists along the east coast. In many States, the total hard clam resource is insignificant in relation to other major fisheries and consequently little effort is expended to obtain the required information. Reliable data are difficult to obtain because most hard clam landings are underreported (McHugh, 1976) and there are only a few scattered estimates of recreational catch.

2.3.2.2. Harvesting pressure. Recreational effort is increasing in nearly all areas. Commercial effort is increasing only in areas where harvestable hard clam resources are still relatively abundant. In approved harvesting areas, productive hard clam grounds are generally declining, and seldom increase even when fishing pressure is eliminated. This is in sharp contrast to observed increases in hard clam populations in areas that are closed to harvesting because of domestic pollution. There is speculation that nutrient enrichment from moderate amounts of domestic pollution may contribute to 
increases in polluted clam populations (McHugh, 1976).

\subsection{Harvesting and Transporting}

\subsubsection{Inclement Weather}

Inclement weather hampers clam harvesting operations. In northern areas, winter ice in harbors and ice accumulation over clam harvesting grounds cause a significant decrease in hard clam landings. In all harvesting areas, severe winds often prevent clam harvesterš from reaching clamming grounds and also from effectively using some harvesting gear.

\subsubsection{Harvesting Methods}

Hard clam resources occur on public and leased grounds. Generally, hand methods alone are legal for harvesting clams on public beds. Hand harvesting methods include: spotting siphon holes, treading, hand raking, bull raking, and tonging. In some States, mechanical harvesting is allowed on leased ground and also on public grounds when water is too deep for hand methods of harvest. Mechanical methods include use of modified oyster dredges, Fall River dredges, hydraulic cage and hydraulic escalator dredges, and patent tongs.

Hydraulic escalator dredging has proved to be efficient in harvesting hard clams, but this dredge causes serious damage to rooted marine vegetation (Menzel, 1976). However, all dredging methods and most hand harvesting methods also damage rooted vegetation. Hand harvesting methods are considered to be relatively inefficient. Despite the known inefficiency, most States report that their hard clam resources are currently being harvested at or very close to their estimated maximum sustainable yield (MSY).

Harvesters are required to return the illegal size clams to the bottom of the harvesting area. The hard clam harvesters grade their catch into three or more trade sizes. The smallest, and most valuable, hard clams are referred to as littlenecks. Harvesters generally receive 3 or 4 cents each for littlenecks or from $\$ 30$ to $\$ 40$ per bushel (approximately 1,000 clams). The second most valuable size hard clam is called cherrystones. Cherrystones are larger than littlenecks, but still small enough to be consumed raw or steamed. Harvesters are paid 3 or 4 cents each for cherrystones. The hard clams that are larger than cherrystones are referred to as chowders and harvesters are paid 1 to 3 cents each, if they can find a buyer.

\subsubsection{Regulations}

The hard clam industry has been more or less regulated by various agencies. The specific regulations for the hard clam industry vary with State, county, town, and federal agencies. Generally, the State or local town conservation agency has had management jurisdiction over the physical aspects of natural hard clam resources. Conservation agencies generally 
Before chemical standards can be established, it is necessary to know which chemicals occur in the environment, whether their chemical form is toxic to humans, and at what levels, and individual consumption patterns. If standards must be established without this information, then the economic implications of setting such standards should be explored.

\section{B. Socio-Economic Issues}

Estauaries suitable for oyster cultivation are also amenable for other uses, many of which are incompatiable with oyster production. In descending order of water quality needed to satisfy each use, the following list (not all-inclusive) has identified competing users of the oyster growing waters and environment. 1 It includes swimming, propagation of fish, shellfish, and wildlife, drinking water, recreational boating, agriculture, industry, sewage treatment, and filling-in of coastal areas for urban development.

\section{Competing Uses}

Oysters require waters of the highest quality, which can also be used for any of the other purposes listed above, since most users tend to lower water quality, use of water is usually governed by tradition. For a new water-use, permission must be obtained from local, state, and in some cases Federal agencies.

\section{High Cost of Research and Services to Clean the Water}

With the enactment of Public Law 92-500 (to improve water quality) and a general concern for the environment, there has been a large-scale effort to reduce pollution. The rationale for this movement often supersedes economic analysis. A public policy decision has been made to improve water quality with the resulting monetary benefits (the water, its animal and plant life, and the surrounding environment) which at times are very hard to quantify. The costs of improving water quality, both in terms of research and actual facilities, are much easier to estimate.

However, as the National Commission on Water Ouality notes, the pace of allocating the public expenditures is behind schedule. ${ }^{2}$ The reasons for this include the uncertainties caused by inflation, inadequate time to formulate plans and finance projects, and the impoundment of Federal monies during 1972-74. In fact, Federal outlays for all pollution control and abatement averaged 50 percent of Federal pollution obligations during 1973-74. 3 For small industrial plants these delays mean added time before they can comply with pollution regulations because their effluents flow into local treatment systems.

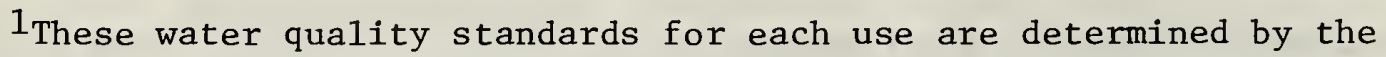
Environmental Protection Agency and the waters tested by each state.

2 Report to the Congress by the National Commission on Water Ouality, Washington, D.C., March 18, 1976, pp. 26-27.

${ }^{3}$ Statistical Abstract of the United States, 1974, U.S. Dept. of Commerce, Bureau of the Census, Washington, D.C., p. 177. 
It should be noted that this report does not attempt to evaluate the benefits and costs of water pollution control vis-a-vis the oyster industry, but only to identify those issues relative to the oyster habitat. Additionally attempting, to justify the national pollution abatement program in light of only one resource or industry would automatically bias any conclusions.

Considerable research as already been conducted by the Environmental Protection Agency (EPA) and State natural resource agencies to define the technologies and abatement costs to reduce pollution of shellfish waters. The next step in this situation is the appropriation of funds to public agencies for construction of pollution abatement facilities and also facilites for and financed by private industry. The EPA and the Council on Environmenta1 Ouality have reported estimates of these costs for the 1974-83 period as indicated in the following table:

Table 1. Estimated Incrementa1 Expenditures for Water Pollution Contro1 in Billions of 1974 Dollars. (a)

Sector

Pub1ic

Federa1

State-local

Private

Industrial

Utilities

Total
Investment

13.0

30.5

3.3
Cumulative -- $1974-83$

Total

Capita1 Annua1

Costs (c) Costs $(d)$

(a) Incrementa1 costs are expenditures made pursuant to federa1 environmental legislation beyond those that would have been made in the absence of this legislation.

(b) Operating and maintenance costs.

(c) Interest and depreciation.

(d) O\&M capital costs.

Source: The Sixth Annual Report of the Council on Environmental Quality (1975), Executive Office of the President, 722 Jackson Place, N.W., Washington, D.C., p. 534.

One other facet of research to improve the water quality is research into the effects of pollution on the oyster itself. In the period 1965-75, approximately $\$ 287,000$ was allocated to research projects dealing with this. ${ }^{4}$ The

${ }^{4}$ From the specific projects, see "Grant-in-Aid for Fisheries, Program Activities," National Marine Fisheries Service, various issues. 
purpose of this research was to establish guidelines and maximum levels from which oysters may be affected by environmental pollution and still remain a safe, wholesome product. The results from this type of research assists in monitoring the quality of the oyster growing waters and in estimating the clean-up costs of those waters.

\section{Net Benefits from Competing Uses}

All the various competing users of the oyster growing waters contribute benefits as well as costs to society. Each provides a livelihood, and in some cases, a way of life. In addtion, economic activity in one industry stimulates economic activity in other industries. The costs to society, in terms of pollution, include demand for medical services, property devaluations, lower crop yields, animal losses, and loss of aesthetic beauty and the quality of life. Therefore, the boundaries that affect oyster culture encompass not only the growing waters, and the industries using them, but also the drainage basins which provide water for the oyster habitat.

There is a theory that the benefits generated by a. industry generally increase as its use of the water intensifies and the quality of the water is progressively degraded. In addition to the absolute dollar value generated by each industry, there are additional economic impacts on society, called multipliers, in terms of total dollar value and of employment. These multipliers are illustrated in the table below for various users on or near the coast.

Indus try

Fishery Products (a)

Food \& Kindred Products

Ag., Forestry, and Fish

Petroleum Refining

New Construction

Other Agricultural Products
Total Value Added Multiplier (in dollars)

$$
3.87
$$

6.06

5.72

5.29

6.17

5.73
Employment Multiplier (in persons)

\subsection{8}

10.48

2.41

21.45

5.58

3.55

(a) For example, a dollars worth of fishery products and one fisheries job generates $\$ 3.87$ in the economy and 3.38 jobs, respectively.

Source: "Economic Impacts of the U.S. Commercial Fishing Industry." Centaur Management Consultants, Inc., prepared for the National Marine Fisheries SErvice, contract No. 4-36756, Jan. 1975, pp. 254-57, 269. 
As indicated in the preceding table, fishery products rank last and next to last in dollar value and employment. multipliers, respectively. However, the large impacts of the other industries are somewhat misleading and may be offset by the environmental costs and they preclude the value generated for society by "cleaner" water users such as oystering.

Also ignored are the benefits accruing from the clean water and environment required for oystering. Thesebenefits come in the form of increased property values near the water and the influx of tourist activity in these areas. The trend in coastal real estate prices is ample evidence of the importance that people attach to such matters.

\section{Economic Criteria for Environmental Improvement}

National expenditures to combat water pollution problems created by competing water users are indicated in Table 1. At the time of this writing, however, there are no accurate estimates of necessary state and local expenditures. ${ }^{\prime}$ A methodology can be proposed which could evaluate the relative worthiness of each project. Also, some insight can be gained into which competing users generate the most water pollution problems.

The methodology to evaluate each project is straightforward. The added value of the precluded water users (from pollution), the value of the lost resource ${ }^{6}$, and the decreased damage and avoidance costs (from pollution) ${ }^{7}$ are divided by the incremental cost of pollution abatement at a particular level of water user. The resulting rat1o 1s the criterion for project evaluation-the larger the ratio, the more worthwhile the project. However, the absolute size of the benefits (assuming they are larger than the costs) is also important. For example, the benefit/cost ratio may be higher for an abatement project in the Mississippi Sound than for a project in the Chesapeake Bay, a prime oyster growing area. When funds are limited, the above ratio, and political considerations, are often used as guidelines.

\section{Nature of Pollution from Competing Users}

\section{a. Domestic}

Among the competing users of water, disposal of domestic sewage treatment is the worst offender. The problem grows with the population which in 20 years from $1950-70$ increased by 50 to 100 percent $^{8}$ in counties with fifty miles of coastal shoreline. Existing sewage treatment facilities are

5 The EPA has only made national estimates based on environmental quality samples taken from selected areas around the country.

${ }^{6}$ See "The Value of the Tidal March," By Gosselink, Odum, and Pope, Louisiana State Univ., May 1974, Sea Grant 74-03, for methodology on valuing a natural resource.

${ }^{7}$ Damage costs are those costs incurred unwillingly as a result of pollution, such as crop losses, medical costs, etc., and avoidance costs are those costs borne to avoid the effects of pollution, such as air filters, treating water before use, etc. See the Sixth Annual Report of the Council on Environmental Ouality (1975), Washington, D.C.

8 Statistical Abstract of the United States 1974, op. cit., p. 9. 
often inadequate and the problem is further compounded by the slow allocation of funds to public agencies for expanded systems. In addition, sewage systems transport various chemicals to the estuaries and some of these may be harmful to oysters and other species as well as adversely affecting their marketability.

\section{b. Agriculture}

Agriculture can be detrimental to oyster culture because of soil movement from plowed fields, pesticide runoff, and animal wastes. The great areas devoted to agriculture, and the large number of operators, make it difficult to identify and control pollution from this source, in contrast to a "point source" polluter such an industrial plant.

\section{c. Industry}

Adverse effects of industrial wastes are difficult to identify, and disposal of such wastes may be difficult to control. Authorities in the Federal Water Pollution Control Act Amendments of 1972 offer promise of reducing industrial wastes. Studies have indicated that pollution control in the production process instead of at the "end of the pipe" results in greater efficiency, and profit. Another positive step is the tax-exempt status given to new pollution abatement equipment by the Commonwealth of Virginia.

\section{d. Recreation}

Recreational boating may also be a source of pollution. Many vessels lack holding tanks for fecal waste. Unfortunately, those which do have them may have to wait for local areas to install systems capable of receiving the waste.

\section{e. Urban Development}

Finally, activities which alter the physical make-up of the coastal areas may cause the irretrievable loss of unique land and water resources. Those activities may be the worst offenders of all in terms of their effect on production of oysters and other estuarine species. These activities include urban development, channel dredging, and filling of marshes, tidal flats, and estuaries. Estauries serve many useful functions: filtering sediment from upstream, providing nutrients and nursery areas for marine life, and even purifying pollution-laden waters. Unless protected by region-wide zoning, such areas may be adversely converted to other uses. At present, the method of valuing of these estauries, a factor in determining their use, is imprecise.

\section{Socia1 Aspects}

The clean environment needed for shellfish growth provides a pleasing aesthetic surrounding for those living and working in these areas. Pristine bays and estuarine waters make these desirable areas, as reflected in the higher real estate values that exist in such areas. The decline of the oyster industry signals a change in all aspects related to the water. The 
changes in the use of the growing waters and habitat come from competing users for the growing water. When these changes take place, those living and working on or near the water are often uprepared.

There are several socal values associated with the use of estuarine areas for oyster production. First, this proivdes a unique way of life to all participants. Considering the opportunity for mobility in today's world, many people consciously choose this form of livelihood and its surrounding environment instead of higher paying positions. In fact, during the period 1950-73, oyster production dropped 36 percent yet employment decreased at only half this rate. Real income per fisherman, corrected for inflation, dropped almost 30 percent during this period. Apparently, there is a strong non-monetary motive to continue as a waterman. In our democratic system, a person should be free to engage in this activity as long as he or she does not interfere with others' activities.

\section{Recreation}

A second social consideration is the recreational harvest of oysters. A great deal of satisfaction is obtained by thousands of people harvesting close to 2.0 million pounds of oysters in their leisure time in a natural, clean environment.

A third factor closely related to recreation is the many other social events centering around the water. Although these events--swimming, boating, fairs, picnicking--do not require as high a water quality as oystering, an appreciation and enjoyment for these events is enhanced by clean water.

\section{Aesthetic Beauty}

One final consideration is the aesthetic value of the resource itself. Many have marveled at the pristine beauty of a mountain meadow or an untouched river system. At the same time, natural resources must be utilized to secure for us a stanard of living. Because most issues are not black and white, pristine beauty is often sacrificed for man's own end. Ten years ago the unseen water, animal and plant life downstream meant little in a firm's profit and loss statement. Today, voices are raised in their defense because of a change in social values. In the end, judgments must be made of the water's value in social as well as economic terms for all uses, including oystering.

\section{Political Issues}

The proximity of oyster growing waters to heavily populated coastal areas fosters many competing uses for these waters. Water resources are deemed a common property and, therefore, are used by many interests including industry, urban development, recreation, and commercial fishing. Any of these uses, if unchecked, could destroy oyster resources. A system of resource allocation and political compromise has emerged to reconcile such competitive uses. The system which emerges varies from state to state, and often within a state, and is dependent, in part, on the specific users involved, their political power, and the jurisdictional structure of authority to regulate multiple use conflicts. 


\section{Competing Uses}

\section{a. Industry}

Manufacturers of ten use water as an integral part of their processing operations or to merely discharge their wastes into adjacent waters. The wastes from power plants, textile, pulp and steel mills, and from chemical manufacturers can degrade oyster growing waters and render them unfit for production unless adequate waste treatment is practiced.

\section{b. Urban development}

Destruction of wetlands, improper road construction, and inadequate domestic waste treatment facilities place a great stress on oyster growing waters. Maintenance dredging, and sand, grave1, and shel1 processing operations can also destroy the resource or lower water quality.

\section{c. Recreation}

Demands for recreational use are increasing with coastal populations and an increased interest in leisure activities. Except in isolated locations around marinas and where boats discharge body wastes direclty into oyster growing waters, water quality is not thought to be appreciably degraded by recreational activities. The aesthetics of clean water needed for enjoyable boating, fishing, and swimming are most in harmony with high qualities required for shellfish growing waters. However, recreational oyster harvesting can pose problems if areas closed to shellfish harvesting are not clearly marked as being polluted.

\section{Politica1 Compromise}

In 1972, Congress enacted the Federal Water Pollution Control Act Amenlments of 1972, Public Law No. 92-500. The Act established national minimal levels of waste treatment for most manufacturing and food processing industries. In addition, a series of water quality criteria based on present and anticipated uses were established to preserve existing water quality. National standards were needed to prevent industries from migrating to States with lax pollution treatment requirements. In theory, the Act should maintain or improve existing water quality. Many people closely associated with the oyster industry fear that because of the industry's small economic size, adverse political compromises are made to accommodate larger labor-intensive industries. Large labor-intensive industry can bring prosperity to underdeveloped rural areas. Jobs, income, and lower taxes are the usual promotional lines. For example, a reduction of water quality to a level still suitable for some forms of recreation could mean a drastic reduction in pollution control costs for local industries, but would exclude the oyster industry. The public decision making bodies would then have a choice between shellfish interests (oysters, watermen, processors, and the cleanest water) or many jobs, industrial prosperity and water still suitable for most uses other than oyster harvesting. 
of course, the above is an over-simplification. In many more cases, industrial development simply outgrows adequate industrial and domestic waste treatment and endangers shellfish grounds. When this occurs, the public's choice is either to require more adequate waste treatment by all or to sacrifice shellfish growing waters. In reaching this decision, an item oftentimes overlooked is that the oyster itself is an indicator of how well an estuary is being preserved and can, in fact, indicate a trend downward in water quality that will eventually impact on users of lesser water quality.

Politics are not isolated to the local levels. Inadequate domestic waste treatment is the largest single factor in closing shellfish waters. Three major reasons for much of the inadequate domestic waste treatment are inadequate, planning, delays in Federal funding and simple, easily understood procedures to be followed to assist municipalities in financing waste treatment facilities. Many people feel that the Federal government has been delinquent in meeting its obligations in this regard.

\section{a. Watermen Lack Organization}

In many areas watermen lack organizations which could present their views before the appropriate political bodies to ensure development of appropriate public policies that would protect shellfish waters and, the watermen's livelihood. The oyster industry doesn't stand alone in the fight for clean waters, and conservation groups should have similar objectives. The oyster industry must take the initiative, otherwise, the 0.6 percent closure of oyster grounds per year can be expected to continue. 9

\section{Institutiona1 Issues}

Institutional issues for the purposes of this report are those issues which could be substantially resolved through legislative change.

\section{Multijurisdictional Authorities}

Growing waters are regulated by various state and local agencies. Such varying jurisdiction causes confusion and difficulty because of the multiplicity of regulations.

Aside from the duplication of effort, varying agencies must compete for limited public funds.

\section{E. Public Hea1th Issues}

After a disease outbreak associated with the consumption of raw oysters, a voluntary industry, state, and Federal control program designed to provide necessary consumer protection was organized in 1925. The program was modified

9"1974 National Shellfish Register of Classified Estuarine Waters." U.S. Environmental Protection Agency, National Enforcement Investigations Center, Denver, Colorado, EPA 33011-75-002-1975, p. 13. 
as new knowledge was obtained and currently it is based primarily upon five factors: (1) microbial classification and sanitary shoreline surveys of the growing waters to ensure suitability of waters from which the product is to be harvested; (2) sufficient on-water marine patrols to assure compliance; (3) requirements for plant construction and hygienic operation; (4) inspection; and (5) product coding and registration of interstate shippers.

The State and Federal health officials interviewed are confident that the current voluntary cooperative program provides adequate consumer protection, but believe it could be improved if a vigorous program of research were directed at the problem. As stated previously, the scope of this review does not specifically address the current voluntary National Shellfish Sanitation Program (NSSP) as such, although certain public health matters that relate to it are discussed.

1. Need for More Precise Correlation of Microbiological Standards with Public Health Relevance

The virus responsible for the particular form of hepatitis which has been associated with oysters cannot be readily and economically isolated and identified. Therefore, an elaborate system of "indicator" microorganisms to indicate presumptive evidence that the virus may be present is used. Unlike testing for routine microorganisms, the failure to rapidly isolate and identify the hepatitis virus precludes the ability to conduct studies concerning reduplication rates, survival rates, time/temperature destruction parameters, etc., the results of which could possibly change the use of the current "indicator" system.

Within the scientific community, there is disagreement over the significance of numerical limits of indicator microorganisms currently employed for classification of growing waters. Microbial indicators are just that, and the presence of indicator microroganisms does not necessarily prove the presence of a particular pathogenic microorganism.

The current microbial limits were apparently in part based upon a study conducted in 1941 on hard clams and may not be relevant for oyster growing waters given 1970's technology. 10 Additionally, there is some concern over the public health relevance of coliforms (total or fecal) elevation due to nonhuman sources such as wildlife pollution. For example, estuaries from which oysters are harvested are of ten located in major flyways for migratory birds. Additionally, in the Pacific Northwest, seals seem to be a contributing factor in elevating coliforms. One commonly expressed opinion is that such wildlife does not harbor diseases which may be significantly transmitted to man via a water route through consumption of oysters. For example, FDA does not differentiate fecal coliforms originating from wildlife pollutants in growing water standards unless such can be proved by a detailed survey. Most researchers agree that the matter needs considerable further

10"Proceedings 9th National She11fish Sanitation Workshop," June 25-26, 1975. Joint resolution by Robert B. MacMillan and William Eisele, p. 75. 
study to resolve the issue. Nonetheless, the rigidity imposed by current numerical limits of coliforms (total or fecal) results in decertification of growing waters which many believe to be suitable for oyster harvesting.

Additionally, many feel that the significance of actual coliform growth (multiplication) in some shallow warm water estuaries is not well understood. It has been proven that such "aftergrowth" does occur and, given the logical assumption that actual microbial pathogen presence in the estuary environment would not multiply at the same rate as indicator coliforms, the public health significance becomes further obscured in terms of precise definition. A further masking of the significance of the coliform indicator system concerns the possibility of "false positives" which may occur due to discharge wastes associated with pulp and textile mills. At this point, it should be reiterated for emphasis sake that the preponderance of opinion of the public health officials interviewed during the course of this review indicated that the current microbial standard in use is adequate for consumer protection, but should answers be forthcoming to the previously described scientific and technical questions, better utilization of the standard could be employed, and, in fact, it may be disclosed that the current standard is too discriminatory.

\section{Multijurisdictional Authority}

Growing water classification authority is generally accomplished by individual State Departments of Public Health under specific guidelines or requirements issued by the U.S. Food and Drug Administration. At the Federal level, this is contrasted with the functions of the Environmental Protection Agency which possesses the major standards setting authority for pollutant discharges into estuaries. Additionally, at the State level, other agencies play a major role and have impact on oyster growing waters. These include State Departments of Conservation, State Air and Water Pollution Control Boards, and local municipalities. For the most part, it appears that some overlap and duplication of effort is being kept at a practicable minimum given the duplication of agencies and authorities involved. Many persons interviewed, however, were of the opinion that the current situation could be further refined through increased training of both state and Federal personnel in the rationale of differing agency requirements and the possible consolidation of some authorities. 


\section{RESOURCE AVAILABILITY}

Resource availability is not limited to merely determining the quantities of oysters on natural grounds, but also covers a number of factors governing the amounts of oysters available for utilization. Assessment of oysters available in terms of numbers and whether they are safe for harvest must be made, as well as the size and quality. Techniques to improve and increase natural oyster production, shellfish depuration techniques, and the use of aquaculture to increase oyster production will all influence the amounts of resource available for harvesting.

\section{A. Technical Issues}

\section{Existing Resources}

\section{a. Resource Assessment}

The location and amounts of oysters and their size and quality must be known for resource management and industry planning.

Maryland is having all of its natural oyster bars resurveyed. Based on a 1906-1912 survey, many areas of the Chesapeake Bay are 1isted as natural oyster grounds and, consequently, harvesting by dredging is prohibited by state law. Side-scanning sonar surveys have pinpointed silted-over oyster beds no longer capable of producing oysters but these areas could provide soft clam dredging opportunities. Additional hard bottoms suitable for oyster production if planted with seed stock have also been located.

Resource assessment must be a continuing activity because of changing environmental conditions and the fluctuating abundance of oysters. Additionally, brood stocks for major seed producing areas must be identified and protected.

\section{b. Water Quality Standards}

Water quality standards are the largest contributing factor segregating resource availability and resources suitable for harvest. As discussed earlier, water pollution has closed 0.6 percent of the nation's oyster beds annually. Fecal contamination and associated potential public health problems require that contaminated waters be closed to harvesting for direct human consumption. The criteria on which oyster grounds are classified as "safe"-is of major importance. The criteria must provide adequate public health protection without being over-restrictive so as to prevent the utilization of oysters which are, in fact, "safe".

Waters must be certified as safe prior to harvesting, and waters which are not classified are prohibited to shellfish harvesting. Water sampling and analysis is a costly, time consuming procedure. The creation of new, rapid analytical techniques could facilitate additional surveys and thereby open areas now closed because they have not been surveyed, and 
allow resurveying of waters previously classified as polluted. Rapid techniques could also provide for more frequent surveys of approved areas to assure public health safeguards.

\section{c. Relaying and Depuration}

Relaying and depuration are usually techniques for purging oysters before marketing by removing them from contaminated areas and placing them in clean waters. The term relaying applies to relocation in natural waters; depuration applies to cleansing in manmade facilities.

Both operations are costly. Relaying requires that the oysters be harvested twice - once for transplanting and again for marketing. Depuration avoids the reharvesting and associated losses due to harvesting inefficiencies, but requires construction and operation of a facility and close monitoring of its operation. In both instances, the time required for the purging operation is based on many factors. Relaying is also used by private oyster farmers to improve growth rates or to fatten oysters prior to marketing.

\section{d. Canning}

Additional quantities of wild oysters could become available if regulations were changed to permit canning of oysters from waters with slightly elevated coliform levels. Commercial sterilization during the canning process kills microbes and, therefore, provides adequate protection against infectious disease. Many persons interviewed believed that the current microbiological standard which requires that raw oysters destined for canning be harvested from waters meeting the same quality standards as those destined for raw consumption may be too stringent. It is believed that no other canned food material must meet such stringent raw material microbiological requirements.

\section{e. Increasing Public Oyster Resources}

Replanting of oyster beds destroyed by natural disasters and disease can increase oyster production in certain areas. Shells planted in areas of natural setting can increase natural populations.

Some states plant seed oysters on depleted beds to augment natural reproduction. Protective measures should be taken to assure that seed stock is free of disease and attached pests or predators. Results of recent research indicate the desirability of planting disease-resistant seed stock.

\section{f. Predator or Competitor Control}

Crabs and ghost shrimp are examples of predators and competitors on the Pacific Coast. Oyster drills are a problem in more saline waters of the Atlantic and Gulf estuaries and on some west coast beds. Starfish are also important predators in New England and the Pacific Northwest. 
Some predators can be controlled by application of specific chemicals, but there would be extremely high costs associated with EPA registration. Further, the use of toxic chemicals is becoming environmentally unacceptable.

\section{g. Aquaculture}

Currently, almost 40 percent of United States oyster production, some 20 million pounds, comes from aquaculture, although most of this production originates from wild seed stock. In some east coast and gilf states where oyster grounds are traditionally considered public property, private culture is discouraged. On the Pacific Coast, however, the entire oyster production comes from private farms which raise the Pacific oyster, Crassotrea gigas, which was originally imported from Japan, and the native oyster, Ostrea lurida. Nationwide production per unit of area under private management far exceeds that in a public fishery.

Although the U.S. oyster industry is fraught with problems - pollution, competition from low priced imports, losses from disease and predators, and increasing production costs - there are, nonetheless, opportunities for greatly increasing production. It is unlikely that significant increases can be achieved by expanding production from wild stocks nor by reliance from imports.11 However, technology of private oyster farming is well known and, coupled with methods used in other parts of the world, U.S. production could be vastly increased. Though suitable space for aquaculture of oysters has decreased, there remain adequate areas for increasing population. With adequate markets and profitability, U.S. production from aquaculture could be increased from the 1973 level of 20 million pounds to at least 35 million pounds ${ }^{12}$, and as much as 80 million pounds ${ }^{13}$, by 1985 .

To attain the production forecast for the future will require the coordinated efforts of federal and state agencies, universities, and the oyster industry. Coordination of efforts will minimize duplication of efforts, and ensure that needed areas of research are addressed. A planning system is needed to define factors which are inhibiting or limiting the full development of oyster aquaculture and identify needed actions. Such a system has been developed by the Center for Quantitative Sciences of the University of Washington as a Sea Grant project and will be used for several aquaculture species, including oysters. This system will provide Program Evaluation and Review Techniques (PERT) network displays to indicate factors inhibiting viable oyster aquaculture and to facilitate the selection of areas needing immediate attention. The input for this system will include published information and evaluation by federal and

${ }^{11}$ Economic Research Division, 1974. Basic Economic Indicators, Oysters 1947-1973. U.S. Department of Commerce, NMFS, Current Fisheries Statistics No $6273,43 \mathrm{p}$.

${ }^{12}$ A Marine Fisheries Program for the Nation, U.S. Dept. of Commerce, Washington, D.C., Nov. 1976, Table 4, p. 69.

13 N.0.A.A. Aquaculture Plan, National Marine Fisheries Service (in press). 
state specialists, university experts, and industry representatives.

Although many problems associated with oyster production have already been identified in this paper, those which are particularly attendant to aquaculture as described in the NOAA Aquaculture Plan are:

\section{h. Space in Suitable Environments}

Oyster culture requires control of space in bays and estuaries which often is desired for other uses. Also, culture requires high-quality water. An alternative is to develop intensive methods such as raft culture to reduce space requirements. Another alternative is to develop intensive culture systems in which oysters could be reared on shore through their entire life cycle under controlled conditions. The University of Delaware with Sea Grant funding is carrying out such a program, and, although it appears technically possible, the economic feasibility has not been determined. The oysters grown in this system will be of uniform size with high meat yields and should demand premium prices, as in the case of the half-she11 trade in New York.

\section{i. Disease and Predator Contro1}

Mass mortalities of oysters occur nearly everywhere oysters are raised. Some causes have been identified and procedures to alleviate certain losses have been developed, but many other losses are unexplained.

\section{j. Inconsistent Supply}

Supplies from public fisheries fluctuate widely from year to year, resulting in uncertain market prices and varying demand. Expansion of private farming would help to stabilize supplies.

\section{k. Genetic Improvement and Selective Breeding}

Since oysters can be reared throughout their entire life cycle in captivity, genetic improvement is possible. These techniques could result in hardy, fast-growing oysters with higher meat yield, and disease-resistant strains. The resultant application would be for both the private grower and enhancement of public grounds.

\section{Seed Supply}

In certain areas, natural reproduction is sporadic and seed production from natural sources is uncertain. Hatcheries may assist in resolving these problems, but hatcheries themselves are subject to their own problems attributed to water quality, disease and food supplies. In a growing number of private endeavors, the hatchery is an integral part of the operation. Although public hatcheries may not replace vast natural sets, they could contribute to the restocking of local, specific areas (particularly those areas devastated by natural disasters), introducing new genetic 
stocks or disease-resistant strains and maintaining genetic integrity of natural stocks. 14

\section{B. Socio-Economic Issues}

In a survey taken of the oyster industry, the most serious problem perceived by fishermen and processors was supply. 15 The major reason for the continued negative trend in supply is closure of beds due to pollution.

\section{Closed Areas}

Five states - Maryland, Lousiana, Washington, Virginia and Texas accounted for 80 percent of all oyster production in 1975. In 1976, a total of 702,000 acres of bottom were closed to oyster harvesting in these five states, representing a waste of resources both in terms of food production and economic value. Assuming that closed areas are as productive as open areas, the lost value to fishermen from 702,000 acres of closed oyster grounds is estimated to be $\$ 2,070,000$. More specific economic studies on productivity could show the actual value of the lost resource to be much higher. Such studies should include the value of seed relayed from closed areas.

Closure of areas to harvesting activities has stimulated interest in relaying and depuration of oysters. An examination of the economic feasibility of these two practices would be of value to the industry.

Application of bacteria-killing processing techniques to oysters harvested from waters of slightly elevated coliforms could increase oyster availability. This method of increasing the supply of oysters should be analyzed.

\section{Seed/Clutch Planting}

Seed and clutch planting are two activities currently used to supplement natural oyster production. The total cost for seed and clutch planting has been reported to range from $\$ .61$ to $\$ .81$ per bushel. 16 Higher seed costs are reported in other areas. Survival rates for seeds planted on public bars have been reported to range from 13 percent to 21 percent 3 or one bushel of marketable oysters for every bushel of seed oysters. 1

${ }^{14}$ Maryland Dept. of Economic and Community Development, 1976. Growth prospect for the oyster industry in Maryland.

15 "Nation Survey of the Oyster Industry's Problems", by Charles L. Vaugh, Boston College, prepared for National Marine Fisheries Service Contract.

16 Interview with M. Paparella, State of Maryland Dept. of Natural Resources, Oxford, Md., July 17, 1976. (45c/bushel for seed oysters, and $35 \mathrm{c} / \mathrm{bushel}$ for fresh shells and $16 \mathrm{c} / \mathrm{bushel}$ for fossil shells).

17 "Growth Prospect for the Oyster Industry in Maryland", Maryland Dept. of Economic and Community Development, Annapolis, Md., Feb., 1976, p. 31. 


\section{Public versus Private Fishery}

In a public fishery, there is little incentive for an individual to improve upon the resource because it is potentially exploitable by everyone. In a private fishery, individuals reap the benefits of their own conservation efforts. Studies reveal that productivities are higher on privately leased bottoms than on public bottoms. 18 Economic inefficiencies imposed upon the fishery by maintenance of public bottoms are serious. Establishment of privately leased property rights would encourage investment in oyster bottoms which in turn would stimulate oyster supply.

\section{Aquaculture}

Cultivating oysters onshore under controlled conditions has been shown to be technically feasible. However, before controlled culturing systems are relied upon as a supply source, their economic feasibility should be carefully examined.

\section{Political Issues}

\section{Competing Uses of Growing Waters}

Aside from the competing uses for growing waters from powerful outside interests, competition exists within the shellfish industry itself.

\section{a. Clammers versus Oystermen}

The soft shell clam industry in the Chesapeake Bay uses escalator dredges with hydraulic pumps to "jet" the clams out of bottom sediments and onto an escalator where they are carried to the surface. Many oystermen believe this dredging can smother adjacent oyster beds and destroy oyster bottoms. If oystermen and clammers are to operate in the same areas, oyster grounds must be clearly delineated and dredging restricted to protect oyster beds. As before, resource management decisions must consider the value of the respective resources in determining appropriate options.

\section{b. Public versus Leased Oyster Bottoms}

Many states lease oyster grounds to private growers. The control the state then exerts on the owner varies. Some states allow owners of private beds to harvest throughout the year, others restrict harvests to coincide with open harvesting on public grounds. Gear restrictions are often lifted for harvesting leased grounds, thereby increasing harvesting efficiencies.

At a 1975 workshop meeting on the Shel1fish Management Program in New York, "...the industry was bitterly divided on the issue of leasing

18"Growth Prospects for the Oyster Industry in Maryland", op. cit., pp. 19-29. 
public bottom for private exclusive shellfish harvest. Generally the independent shellfish industry was opposed to any new leases..."19 The commercial companies contended that these areas are vital to their survival if they are to develop aquaculture to its maximum value.

Exact causes of disagreement are not specified, but apprehensions are that: (1) the more grounds a state leases, the less effort it will provide in improving public beds, and (2) the addition of large numbers of oysters from aquaculture farms would increase local supplies and depress prices that would reduce the value of the independent harvester's catch.

\section{Cost/Benefit of Habitat and Stock Improvement}

The improvement of oyster grounds can include a wide variety of actions, such as reducing pollutants entering the growing areas, shell planting, planting of seed oysters, developing genetic improvements in oyster stocks, pest eradication, and massive relaying operations.

Each action, with the possible exception of enforcing existing pollution control regulations, requires increased financial expenditures. In developing management options, anticipated benefits, costs, and cost sharing options should be determined.

States can bear the costs directly or impose taxes on each bushe1 of oysters harvested to defray the costs of shell planting, seed stock hatcheries, and relaying. Another approach is to lease oyster grounds to private firms and incorporate management and conservation practices into the leases, leaving public grounds supported by natural oyster production available to independent harvesters.

Whatever the options presented, the costs of improving natural oyster production must be weighed in terms of increased revenues, increased numbers of jobs for watermen and shucking plant personnel, reduction of state welfare and unemployment payments, and local community development.

\section{Multijurisdictional Authorities}

The usual mix of state agencies responsible for oyster growing waters and oyster resources include the State Water Pollution Control Boards, the Departments of Health, and the Departments of Conservation. Maximum resource utilization depends on the cooperative efforts of the agencies. The maintenance of high water quality will be heavily dependent on the effectiveness of enforcement of pollution control requirements. In turn, the success of efforts of the state's Departments of Conservation to improve the resource will be dependent on good water quality. The ultimate utilization of the resource will be governed by the Departments of Health's ability to accurately survey and classify oyster growing waters. A 1ack of funds and personnel could result in lack of requisite growing water

${ }^{19}$ Workshop proceedings on the shellfish management program, N.Y. State Dept. of Environmental Cons. and N.Y. Sea Grant Inst., July, 1975, p. 49. 
certification and close these waters to shellfish harvest, thereby negating efforts to curb pollution and enhance oyster stocks. Conversely, lack of adequate surveys could also lead to waters remaining certified when they should be decertified.

\section{Public Health Issues}

The factors that affect the quality of the growing water and the environment are also those which affect the availability of the resource. For example, for whatever reasons a sanitary survey would place restrictions on the water in which oysters grow, these same reasons would prevent the availability of the resource.

\section{Dispute on Significance of Indicator Microorganisms}

The numercial limits of indicator microorganisms used to determine sanitary acceptability of growing waters are subject to dispute within the scientific community relevant to possible foodborne outbreaks of disease.

The dispute over coliforms and fecal coliforms, particularly as accurate indicators of fecal pollution, raises the question whether "false positives" are really fecal coliforms. If organisms such as Klebsiella from pulp and textile mills are considered indicators, then beds in the vicinity of such plants would be closed.

Additionally, there is dispute on the public health relevance of wildlife pathogens in terms of possible foodborne outbreaks of disease, particularly in the case of products receiving commercial sterilization prior to consumption. Also, there has been evidenced some concern for the possible presence of micobial pathogens other than Salmonella or hepatitis virus. Although reported isolations of other pathogens have been extremely rare, nonetheless, the possible public health significance needs to be determined.

\section{Need for Chemical Standards}

As has been referenced earlier in this report, chemical standards are currently placed on the final shucked product which is appropriate from a public health perspective. There is a need, however, to run well coordinated baseline studies to determine specifically what chemicals, and in what quantities, one can reasonably expect to find associated with oysters in the major producing estuaries.

After such is done, necessary applied toxicological studies relating to chemical forms of toxicants, potentiation, sequestering, and/or masking effects, if any, and consumption patterns of the population at risk should be undertaken in order to determine forecasting needs for chemical standards.

\section{Remote Monitoring}

There is a need for innovative techniques to rapidly and remotely monitor water quality which, in turn, affects resource availability. The 
more rapidly results could be obtained from growing waters, the less turnaround time one could expect relative to making decisions concerning utilization of the resource. Such monitoring systems could allow for rapid identification for potential problem areas or expedite reopening of areas which had previously been temporarily closed. Another area for use would be remote waters as are found in Alaska. An additional feature of such a system would be that it could allow for sampling and analysis during periods of severe hydrographic changes which are currently most difficult due to impracticability of obtaining samples using a small boat in stormy weather. One complaint voiced during the interviews was that the government could remotely analyze, monitor, and transmit results through telemetry systems of bioinformation from distant planets, but not on estuarine waters. Another form of remote monitoring which is currently available and used in some areas is radar surveillance to prevent harvesting oysters from noncertified waters or prevent theft in a private fishery. 


\section{HARVESTING}

\section{A. Technical Issues}

\section{Gear Development}

Lower cost gear should be developed to reduce labor, improve catch recovery, and reduce damage to recovered oysters and to oyster bottoms.

Labor-intensive is the common denominator to most of the current harvesting techniques. The majority of oysters on public beds are harvested by tonging and dredging. Hand tonging is the most common harvesting technique on shallow reefs in protected rivers and bays and in often most efficient in such areas. Patent tongs and hand dredges are used in deeper waters. In Maryland some oysters are also harvested by a small remnant fleet of the once dominant skipjacks (large sajl-powered workboats which tow dredges), power dredging being prohibited except for two days a week. Except for escalator dredges commonly used for soft clamming and on private oyster bottoms, most oyster harvesting is labor-intensive and inefficient in recovering all legal size oysters.

In many areas of the country where private oyster farming is practiced, such as the Pacific Northwest or Long Island Sound and other areas, large, efficient dredges mounted on self-propelled or towed barges are used. Unfortunately, their cost is beyond the reach of most sma11 operators.

Selective harvesting gear could possibly improve efficiency by eliminating the hand culling of live marketable sized oysters from shell and debris when oysters are brought aboard the vessel. The hydraulic escalator dredge offers such possibilities. In private areas under cultivation, harvesting techniques should assure recovery of the marketable crops.

It must be recognized for any gear under consideration for development that reducing mortalities is important for transplanting seed oysters, relaying, and for delivery to processors. The effect of various harvesting techniques on small thin-shelled seed oysters should be determined. The minimizing of damage and stress in harvesting oysters for relaying is also important as only healthy oysters will resume feeding and purge themselves in the time allowed for cleansing. Preservation of oyster beds from damage during harvesting is also an important factors.

\section{Quality Factors}

Different factors affect the quality of oysters from time of harvest until their arrival at the shucking house for processing, or direct sale as shellstock, and must be recognized to assure consistent high quality. Seasonal and geographical variations affect oyster yields and quality.

Following spawning, oysters are generally watery and give poorer yields when compared to their fat, plump, prespawning condition. Coliform counts used as quality indicators of oyster meats will vary with seasons and locations. 
Holding conditions during transport, including times, temperatures, humidity and coliform growth rates, should be carefully examined to determine optimal handling of shell stock under a wide variety of seasonal and geographical conditions. These factors apply on the vessel and during shipment by truck, rail, etc.

The importance of these factors may depend greatly on how the oysters are to be used. Conditions optimal for holding seed oysters and those for relaying may differ significantly from those for holding oysters for processing or raw consumption. For example, constant spray irrigation to cool oysters and reduce stress during transplanting may well cause increased mortality. Although most States have standards relative to holding and shipping conditions, there seems to be no uniformity of agreement on such standards.

\section{B. Socio-Economic Issues}

Productivity, total landings, number of fishermen, deflated exvessel prices, and deflated income for fishermen all show declining trends. There is an array of vessel and gear in the industry with various rates of productivity and profit. In this section, facets of the harvesting sector are explored, identifying problem areas and needs.

\section{Prices}

Eastern oyster prices fluctuate considerably during the year due to several factors. The timing of the season, and its effect on the supply and demand of oysters, influence price a great deal. The yield, size, and quality of oysters also influence price.

\section{Gear}

Four types of gear are used to harvest oysters--the hand tong, patent tong, towed dredge, and escalator and hydraulic dredges. Physical characteristics of the oyster beds often determine the type of gear employed. Technical productivity coefficients reported for these gear types vary between 6 to 30 bushels per day per man for hand and patent tongs, and average 1,400 bushes per day per man for the larger power dredges. 20

Because of their high relative productivity, dredges have become the dominant method used to harvest oysters in some States. At the present time, the most intensive $\mathrm{se}$ of dredges is on private bottoms.

\section{Regulations}

Regulations have been developed to govern the harvesting of oysters on public beds. These regulations deal primarily with property rights, use of

20"The Atlantic Oyster Fishery," A. Sokoloski, T. Gaucher, A. Koers. R. Kelly, University of Rhode Island, Kingston, R.I., 1973, p. 33. 
gear, and catch quotas.

The decision to leave the oyster fishery as a public free access one is largely based on political tradition and arguments of a social nature. Although it can be shown that firms operating on private or leased bottoms produce a higher output and earn greater net returns, economic considerations are put aside in some areas and replaced by tradition and/or social values.

\section{Labor Force}

In 1973, there were 11,748 ful1 and part time oyster fishermen in the U.S. and this number has been decreasing. There were approximately 14,000 harvesters in the 1950 's. Virtually the entire decrease was among the tongers.

In addition to the declining number of harvesters, the average age of the oysterman has been increasing. In a study of Maryland oystermen in 1972, the average age of licensed oystermen in four different localities varied between 41 and 46 years; 20 percent of the oystermen were in the 45-54 age group; and 47 percent of all oystermen were 45 years of age or older. 21 Education levels of the oystermen are below the national average. The Maryland study also found that only 30 percent of al1 oystermen completed the 7-8 grade and 28 percent completed high school. 22

Vocational training is another aspect of education. Only 23 percent of the oystermen had some form of vocational training; out of this group 74 percent said they had used their acquired skills in the last five years. 23 Participation in vocational education training was found to be inversely related to the distances from urban centers.

\section{a. Job Esteem}

Oystering is an established way of life in many areas. The independence of the oyster fisherman explains a great deal of the hostility towards a private fishery. Opponents of a private access fishery argue that (1) it prevents mobility within and free entry/exit from the oyster beds and (2) it breaks down established employer/employee relationships.

Even though a private fishery may provide as many jobs as a public fishery, the philosophy of the independent oysterman often prevails. This sort of philosophy is basically equivalent to the outlook of independent agricultural operators. Usually, when the income of small farm operators drops to the level of their next best employment opportunity, few of the small farmers transfer to a different source of employment. This indicates a strong social independence. A study of small farmers indicated that they

21 "An Appraisal of the Alternative Earning Power of the Maryland Oystermen," R. J. Marasco, National Shellfisheries Association, 1972 Proceedings, Volume 63 , June 1973, p. 48.

22 Ibid., p. 49.

23 Ibid., pp. 49-50. 
do not leave farming until personal incomes fall below the "psychic value" received from their way of life. 24

\section{b. Alternative Employment Opportunities}

Job alternatives for oystermen depend on the fisherman's age, education, experience, and location. In the Maryland oystermen study, a large number of oystermen indicated they received income from other sources-from water related activities (finfish, clams, and crabs) and/or from nonfishing employment. In the Maryland study, of the 845 oystermen who had more than one source of income, 44 percent obtained income from non-fishing employment, and 56 percent from harvesting clams, crabs, or finfish. 25

In a followup question, oystermen were asked what action they would take if there was a failure in the oyster fishery. Fifty percent responded that they would find employment in non-fishing jobs, 17 percent were undecided. 26

A table was constructed classifying all the oystermen interviewed into three groups: potentially employable, possibly retainable, and potential hard-core unemployable. Based on this system, the largest numbers in the potentially employable group lived near urban population centers. 27

\section{Financial Assistance}

The small size of most oyster operations and the inherent risk involved often make financial assistance difficult to obtain from traditional sources. Federal financial assistance is available from three agencies--National Marine Fisheries Service, Farm Credit and Farmers Home Adminiatration, and the Small Business Administration.

Loan obligation guarantees are available from the National Marine Fisheries Service for vessel construction and improvement. Previously there had been a 5-net-ton minimum size requirement for this program, and so that only ocean-going vessels qualified. The minimum size requirement for this program has since been reduced to 2-net-tons. Financial assistance is also available from the Economic Development Administration, subject to location, owner's equity, and constraints on the industry's capacity utilization rate.

Financial credit from agricultural sources is available for both short and long-term loans. The Production Credit Association (PCA) has provided operating loans to fish farmers for some time, but all harvesters are now eligible under the Farm Credit Act of 1972. Because the PCA's are regional in nature, and are farmer-run and owned, authorization of loans to the fishing industry has varied considerably among localities. Only in areas where

${ }^{24}$ Foundations of Farm Policy, Luther Tweeter, U. of Nebraska Press, Lincoln, Neb., 1970, pp. 171-176.

25 "An Appraisal of the Alternative Earning Power of the Maryland Oystermen " op. cit., pp. 49-50.

26 Ibid., pp. 50-51.

27 Ibid., pp. 50-52. 
there already is a strong fishing industry or tradition prevails that loans are made with regularity. Long-term loans for construction and purchase of equipment are also available to fish and shellfish farmers from the Farmers Home Administration.

Financial assistance from the Small Business Administration appears among the most flexible source of financing, but this program is hampered by a shortage of funds for direct loans, and the fishing industry must compete with small firms in all other businesses.

\section{Political Issues}

Natural oyster resources provide many benefits in terms of employment, food, and State revenues. Watermen and seafood processors depend on the resource for their livelihood, and, therefore, have a vested interest in its management. The oyster industry should work with State and Federal agencies in formulating legislation which governs resource protection, utilization, and promotes industry stability, which is of major importance in realizing the resource's full benefits. Key policy decisions would include: harvesting quotas, gear restrictions, conservation, the control of bootlegging (harvesting oysters from non-certified waters), and options of resource utilization.

\section{Lack of Industry Input Into Public Policy Decisions}

Many associated with the harvesting segment feel they lack input into public policy decisions.

\section{a. Harvesting Quotas}

Quotas are commonly established either as a conservation technique to protect the resource, as a means of stabilizing the market price, or for social purposes. Such approaches can indeed be related, but at the outset, each should be clearly delineated so as to surface any needs for change.

\section{b. Conservation Quotas}

Conservation quotas reflect the total allowable harvest, based on maximum sustainable yield (MSY). Oyster harvesting quotas are commonly based on a season of a prescribed number of days. Fishing effort is then approximated by the number of harvesters, the efficiencies of the gear used, and the days open for harvesting. Daily quotas are based on the total allowable catch MSY divided by fishing effort.

In other fisheries, quotas are often based on the MSY alone. The opening of the season is determined by biological factors and continues until the total MSY is attained.

\section{c. Marketing Quotas}

Marketing quotas must consider a wide array of factors including: availability of raw product (partially based on harvesting capacities), 
keeping quality of raw product, processing capabilities, product shelf life, seasonal product demands, and marketing flexibility.

Oyster production is in many ways unique from other seafoods. Fresh oyster sales account for 75 percent of the oyster domestically harvested. The raw product is highly perishable, and the processing is labor intensive. Product shelf life is generally less than two weeks. The major demand for fresh oysters is from September through April, with heavy sustained demand during the Thanksgiving and Christmas holiday seasons. The smooth flow of material from harvest through retail sales is essential to avoid wastage. Therefore, oyster harvesting quotas must account for both resource and market protection to assure maximum sustained benefits.

\section{d. Social Purposes}

Among the concerns regarding the social aspects of resource management are considerations to minimize conflicts between user groups of the resource or adjacent resources, and through maintaining maximum employment, conserve a traditional culture for numerous watermen.

\section{e. Harvesting Gear Restrictions}

Many believe that gear restrictions for purposes other than protecting oyster grounds from damage and undue stress during harvesting should be carefully re-examined. Some gear restrictions produce harvesting inefficiencies which increase costs and deprive watermen of potential income. Harvesters are faced with continued increases in operating costs and yet today only receive a real income similar to that of 20 years ago. Increasing costs of fuel and equipment are two of many costs which reduce his take-home wages.

The point was often made by those interviewed that gear restrictions should not promote inefficiencies. If a waterman's boat can handle two dredges, he should not be limited to one and thereby make twice as many trips, consume twice the fuel, and waste additional manpower for the same catch that a single trip with two dredges could yield. If catch quotas must be made, an option should be available to reduce allowable fishing days as gear efficiencies increase, and such would yield the same catch, but save fuel and allow watermen to seek additional employment to supplement their incomes.

Watermen should have a voice in making these decisions. Processing plant capacity and the perishability of the oyster must also be considered. Limited production capacities in some areas may preclude greater daily quotas without resultant less of demand.

\section{Bootlegging}

The elimination of bootlegging, or harvesting oysters from non-certified waters, is important to the States, industry, and consumers. Public health outbreaks associated with shellfish consumption weaken consumer confidence, and can adversely affect all oyster sales. 
The industry should be instrumental in seeking sanctions to eliminate bootlegging. A concerted State/industry educational effort is needed to ensure that penalties are commensurate with the danger that bootlegging poses to the public's health. Bootlegging, too often, is regarded as a misdemeanor tried by the local Justice of the Peace.

Other States have much more severe criminal and civil sanctions which include confiscation of vessel and gear. However, if a State seizes a vessel, it must store and be legally responsible for it until the case is adjudicated. Since enforcement programs are often understaffed, few vessels are sized.

\section{Planning Industry Stability}

The commercial harvesting, processing, and marketing of oysters is the only way the full economic benefits of oyster resources can be realized. The States should therefore work with the industry to promote industry stability which will provide jobs, increase State revenues, and lessen expenditures for welfare and unemployment.

\section{a. Over-Regulation}

Over-regulation should be viewed as a threat to industry stability, as it produces inefficiencies which decrease production, increase costs to consumers, and can lead to plant closures and job losses, all without providing tangible benefits. The need for regulations should be documented in terms of benefits together with their technical, economic, and administrative hardships prior to implementation. Proposed regulations should also be viewed in concert with existing or proposed regulations impacting on the industry by other agencies, e.g., EPA, FDA, OSHA, FED, State and 1oca1 health, conservation, environmental, and zoning regulations, to prevent compounding hardships.

\section{b. Financia1 Support}

Financial support is needed by State agencies responsible for managing oyster resources, classifying growing waters, and assisting the industry. As applied to harvesting, the industry should use its influence with State legislatures to secure funding for adequate water surveys so that al1 "suitable" oysters can be harvested, and seek increased efforts in patrols or judicial proceedings to eliminate bootlegging. Additionally, such support would prevent unsuitable waters from remaining open. Should insufficient State funds be appropriated, the industry may wish to consider sharing financial responsibilities.

Often the industry provides monies for state conservation and oyster ground maintenance through taxes levied on each bushel of oysters harvested. Similar levies provided overhead on collection was kept to a minimum, could ensure adequate water classification surveys and patrols which offer industry stability. 


\section{Institutional Issues}

\section{Public Assistance Opportunity Competition}

Numerous persons associated with the industry believe there is a striking institutional ambivalence with certain institutional regulations. For example, on the one hand it is stated that many regulations are designed to maintain a traditional culture among harvesters in terms of a free spirit of independence and "quality of 1ife" which emphasizes hard work and a sense for the dollar. On the other hand, many feel that certain types of public assistance programs, while not designed to do so, in fact encourage "laziness" and instill a set of values to the recipient counter to hard work, independence, and a sense for the dollar. Obviously, such sentiment is an oversimplification to a complex issue, and no easy resolution is possible. One constantly voiced complaint, however, was that public assistance type programs have a competitive advantage in the labor pool market over watermen who need occasional labor assistance in harvesting oysters.

\section{Multijurisdictional Authority}

This situation exists in the harvesting segment as well. The solution will not be a simple task. Due to the varying mission orientation of the numerous agencies impacting on the harvesting segment, a great deal of paperwork and record keeping are imposed on the individual harvester. One common suggestion proposed through the industry interview phase of this review was a need for the differing agencies having jurisdiction to write regulations in wording which could be easily understood by those regulated, conduct indepth interagency review of proposed regulations to assure no conflict with other agency regulations, and finally, for agencies to provide training where needed to those to be regulated in terms of understanding, and making practicable compliance procedures.

\section{E. Public Health Issues}

The public health issues associated with harvesting and transporting the resource to a place for processing are primarily twofold, i.e., bootlegging and maintenance of vessel and truck sanitation standards to assure product acceptability maintenance prior to processing.

\section{Bootlegging}

This potential problem was identified earlier in this report, and it is not the intent in this section to reiterate previous discussions. Throughout the conduct of this review, opinions varied greatly on the magnitude of this potential problem. One aspect of the problem not previously discussed relates to illegal harvesting of oysters from noncertified (restricted) waters by sportsmen or persons for private use.

A preliminary survey on reported outbreaks of hepatitis indicates that there may have been more outbreaks of the disease resulting from recreational harvesting than from commercial harvesting, and therefore, illegal 
In areas of the country where intensive private oyster farming is carried out on either individually owned or lease bottoms, such as the Pacific Northwest, bootlegging does not appear to be a problem. There the problem is piracy or stealing of privately owned, and perfectly safe to eat, shellstock.

Another potential problem associated with illegal harvest of oysters relates to the perfectly sound practice of "relaying," as Kelly pointed out in 1971.
"Relaying of shellfish from polluted to clean waters has been practiced for centuries. This proceudre exploits the well-known ability of mollusks, by way of their feeding mechanisms and other physiological processes to attain equilibrium with the new aquatic environment. Equilibrium is attained fairly rapidly in the case of bacteria and viruses, but, in the case of metallic ions and toxins, it proceeds slowly, requiring many months with some agents.
"Relaying involves some risks. These include mortality of shellfish and the continued possibility of poaching. Little can be done about the former, except to conduct the activity at periods of optimal activity of the shellfish and to avoid as much as possible the opportunity for the ravages of predators. Poaching can be minimized by proper selection of the clean water area, tight patrolling of the area, and control of harvesting, planting, and reharvesting." 28

It is essential that State programs charged with surveillance and enforcement of restricted growing waters be adequately funded to carry out their responsibilities, and that all who harvest oysters understand and accept need to protect the public health by properly classifying growing waters.

Another aspect of growing water classification procedures that should be re-examined is the "closed safety zone" or "buffer zone." Currently, there are requirements that:
"...a closed safety zone (buffer.zone) is established between the conditionally approved area and the source of pollution to give the State agency time to stop she11- fish harvesting if performance standards are not met."

28"The Health Hazards Associated With the Consumption of Shellfish From Polluted Waters," C. B. Kelly, Environmental Protection Agency, Division of Water Hygiene, September 1971.

29"Part 1. Sanitation of Shellfish Growing Àrea." 1965 Revision, U.S. Dept. of Health, Education and Welfare, Public Health Service, Division of Environmental Engineering and Food Protection, Washington, D.C. 
Such waters in the closed safety zone are not polluted, but serve as a buffer should a problem occur. Many persons interviewed agreed with the principle but suggested modification to take into account design and construction of contemporary sewage treatment plants. The most frequent modification suggested was to provide incentives by decreasing buffer zones when plants are equipped with such fail-safe devices as 24- to 48-hour holding ponds (that are automatically utilized by process failure), dual chlorinators, dual and automated power systems, sealed pumps, sand-filtered effluent, etc.

\section{Vesse1 and Truck Sanitation Standards}

Although there are sanitation standards for vessels and trucks, requirements and enforcement appear to be nonuniform. Such standards should include design and holding capability of vessels and trucks, methods of cleaning, prevention of cross-contamination, temperature control, and take into account the location in which various vehicles operated. The requirements for design and operation of vessels may vary with climate and harvesting season; however, uniform standards for maintaining shellstock would have to be met. 


\section{PROCESS ING}

\section{A. Technical Issues}

\section{Lack of Mechanization}

Processing oysters for the fresh or frozen trade is still a high cost, labor-intensive, hand-shucking operation. The average age of the oyster shucker is increasing, and the work is generally attracting only a very few young people. Should this trend continue, hand shucking will be a thing of the past. Several attempts have been made to mechanize oyster shucking, but a successful mechanical shucker that is acceptable to the industry is not available. The task of mechanically shucking clusters of oysters is virtually impossible.

Washing procedures are not standardized throughout the industry. Some people believe nonuniform washing procedures have often resulted in excessive liquor loss in shucked oysters at the retail level. Better packing techniques must be developed and employed to prevent retail customers from tampering with contents of the container. Many persons who are associated with the processing industry were interviewed and cited lack of mechanization as the most serious issue facing processors.

\section{Limited Product Forms}

Most oysters are sold fresh, canned, or frozen, with only a small amount of production going into specialty items such as seafood gumbo, oyster dressings, oyster stuffing, and oyster stew. New product forms must be developed to allow the processor to expand production. For example, the expanded field of "fabricated foods" appearing on the U.S. market could include some types of oysters not suitable for present markets, such as the overly-large Pacific oyster. Additionally, new products such as dehydrated soups, stews, gumbos, etc., could be developed. Pasteurized products are another likely avenue for expansion. This would require time/temperature studies necessary to ensure product safety and shelf life. Most oyster processors have neither the capabilities nor the funds to support research projects of this magnitude. A major concern of processors throughout the country was that, should the Federal government initiate a largescale product development program, safeguards (in the form of tariffs, etc.) should be included to prevent foreign processors from utilizing the new technology and, because of less regulation and a lower labor cost, flooding the U.S. market.

\section{Need for a Practicable Quality Standard}

Due to the differing species and geographical locations, industry processing techniques vary, resulting in differing product characteristics such as drip loss, pH, etc. Many believe current quality standards are not practicable due to the aforementioned variables. All agree that there should be national standards, but such should be based on regional product characteristics. For example, there could be a national drip loss standard, but that standard would have different limits for different species, geographical locations, and seasonal harvesting times. 


\section{B. Socio-Economic Issues}

\section{Labor}

Due to the lack of mechanization, labor is the major input in the shucking operation. Currently, labor accounts for 32 perçent of all operating costs incurred in the processing of shucked oysters. ${ }^{30}$ Labor is also a major cost component in canning and breading operations. Because of such high labor components, rapid increases in labor costs are a source of concern.

The shortage of shuckers has heen cited by industry spokesmen as a major problem facing oyster processors. 31 In a Maryland study, the shortage of shuckers was estimated to be 1,260 in 1973, an increase of 510 over the 4-year period from 1969.32 Several factors contributed to this situation: (1) the seasonal nature of production makes employment uncertain (in many plants only half the peak winter work force is employed in the summer), (2) employment and retirement benefits are minimal, and (3) low wages make other forms of employment more attractive.

\section{Transportation}

The small size of most oyster processing establishments often makes it unprofitable for them to provide their own transportation of processed products. The most frequently used method to transport processed oysters is the common carrier. Often much time is spent in locating a common carrier onto which oyster products can be "piggy-backed." This practice has on occasion resulted in improper product handling.

\section{Foreign Competition}

Competition from foreign suppliers of canned oysters is a source of concern among domestic processors. Quotas, currently, are nonexistent. However, a duty is charged on canned imports (fresh and frozen products enter duty free). Foreign processors enjoy a favorable competitive condition in the processing of oyster products due to lower labor costs and government subsidy assistance.

\section{Financial Credit}

Several factors make it difficult for oyster processors to obtain financial assistance. Physical facilities in many instances are aged and in poor condition. In addition, the lack of an assured raw material supply contributes to the difficulty oystel processors have in obtaining loans.

\section{Product Liability}

Legal precedents have established that manufacturers are responsible for the wholesomeness and safety of their product even if it passes through

${ }_{31}^{30}$ Personal communication. David Dressel, National Marine Fisheries Service.

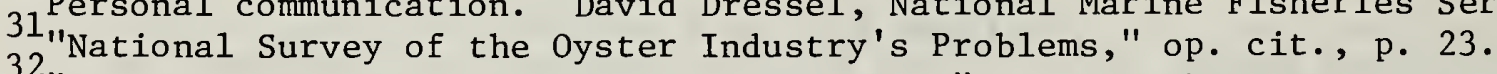

32"Engineering Approach to Oyster Processing," Fred W. Wheaton, Transactions of the American Society of Agricultural Engineering, Vol. 14, No. 1, 1971. 
several hands before reaching the final consumer. Therefore, when retailers and wholesalers do not properly care for the product, the oyster processor is legally liable.

\section{Political Issues}

\section{Competing Use for Land Space (Zoning)}

Processors must have suitable land which is frequently denied because of zoning requirements. Zoning influences the ability of the processor to meet pollution control and sanitation requirements. Often the land required to install sophisticated pollution treatment equipment is not available, and zoning can prohibit plant tie-ups to municipal waste treatment facilities. Similar restrictions on plant size and constructions may prohibit the addition of new cold storage facilities needed to modernize older plants or to comply with sanitation regulations. Limiting plant expansion can also influence production efficiencies. Local zoning and taxation can be powerful political tools in eliminating processing plants from waterfront areas that are in high demand for leisure, housing, or other commercial development.

\section{Lack of Industry Input into Public Policy Decisions}

Perhaps in the final analysis, particularly at the local level, the industry lacks what is generally referred to as "clout." Being a small and fragmented industry, it does not have the capital to hire skilled professionals and others to present their particular viewpoints before public decisionmaking bodies. In many cases, the processors themselves are not equipped with the necessary knowledge of the interworkings of government to adequately defend their particular points of view.

\section{Institutional Issues}

\section{Multijurisdictional Authority}

The oyster industry, like many other food processing industries, is controlled by numerous Federal, State, county, and sometimes local regulatory agencies. Such authorities promulgate regulations covering environmental protection, plant construction, product quality and safety, and revenue and tax collection. The industry is small and diverse, and of ten lacks the expertise to cope with the technical, economic, and administrative requirements imposed by the regulatory agencies.

\section{a. Plant Construction, Maintenance, and Safety}

Pollution control requirements are one of the most immediate problems facing the industry. National effluent discharge guidelines have been establised dictating minimum treatment requirements. In addition, State and county regulations, which may be more stringent, are often in effect. The degree of enforcement and compliance varies from state to state and may be dependent on the delegation of enforcement authority to lower levels of local government. In addition, changes are often required to meet new public health and employee safety (OSHA) requirements. 


\section{b. Product Safety}

Sanitation and product safety is under scrutiny by numerous Federal, State, and local inspection personnel, in addition to private inspectors hired by the firm. At the Federal level, it is possible to find an FDA, NMFS, and DOD simultaneous inspection of the plant and product, and each may reach a different conclusion due to differing standards or disagreement over interpretation of regulations. The problem can be further compounded at the State or local level.

\section{c. Administrative and Record Keeping}

As stated earlier in this report, the oyster processor is under numerous inspections and record keeping requirements. Such requirements should be examined closely to see if consolidations are possible to improve in-plant efficiency.

\section{d. State Overseer/Coordinator}

The multiple agencies and jurisdictional authorities governing the safe and efficient production of oyster products are many and their interactions complex. A high level State agent or task force to act as overseer of the State's entire effort to develop benefits from oyster resources could be most beneficial. The State coordinator could coordinate activities of the numerous State agencies involved, promote systematic funding, view the need for State and Federal legislative changes and, in genera1, assist in providing the multidisciplined guidance and supervision needed to assure a viable oyster industry providing maximum state benefits. Studies are needed to find ways to systematically improve the oyster industry.

\section{e. Reciprocal Agreements}

The split jurisdictional regulations and delegation of authorities to different levels has produced a cumbersome administrative system with apparent duplication of effort. Practicable and workable reciprocal agreements between Federal, State, county, and local authorities responsible for pollution control and sanitation standards could possibly reduce the number of plant inspectors and improve plant efficiencies. A system of cross checking with record and inspector exchanges could be incorporated to assure uniform application.

\section{f. Mu1tipurpose Record Forms}

Record keeping is one of the major daily problems facing small independent oyster processors. The development of a multipurpose record form could greatly simplify administrative procedures. An example of needed improvement could be in the record keeping of harvesters' slips the packer makes on the arrival of oysters at the shucking house. A condensed multipurpose form with several copies could provide the following: Federal and State taxation data for processors and watermen, record of oyster harvests for conservation taxation and management, assist industry in tracing origin of oysters and in reducing bootlegging. Similar record consolidation could be made for pollution control and sanitation inspections agreements. 


\section{E. Public Health Issues}

\section{Dispute Over Significance of Indicator Microorganisms}

There are widespread disagreements among regulatory agents, industry members, and scientific groups in regard to the significance of fecal coliforms as an indicator to determine the sanitary quality of oysters. Some agrue that these organisms can be found in significant numbers in waters far removed from sewage polluted areas. Consequently, their presence in the product is subject to question. Also, there are some disagreements on the methodology used to identify and enumerate these organisms. Many question the validity of the number of organisms in the product to signify product quality. There is some concern that the value of 230 fecal coliforms has not been sufficiently correlated with potential public health hazards. There is a real need for the development of practicable methods for detection and/or isolation of hepatitis virus(es) from oyster meats. Since hepatitis is the main cause of public health concern associated with consumption of raw oysters, were it possible to detect such virus(es) in oyster meats in a practical fashion, the processor would have a means of screening products and of increasing consumer confidence in his product.

\section{Relationship Between Heat Processing and Pathogen Destruction for Non- Commercialized Sterilized Products Such as Pasteurization}

Therma1 processing (pasteurizing) offers new avenues for utilization of misshaped and clustered oysters, and preparation of products for further processing should be further investigated. Process parameters necessary to eliminate heat-resistant pathogens from shellstock must be evaluated to determine the optimum conditions for quality maintenance and maximum yield of a safe product.

\section{Need for Practical Lot Coding and Segregation to Trace Oysters to Growing Waters}

There is a need for a practical lot coding system so that non-approved oysters will not be shipped by the processor, and, if mistakes occur, the location can be traced and suspect oysters can be segregated without necessarily suspending all plant activity.

The current tagging procedure could be improved, particularly in the case of "sacked" oysters where tags may fall off due to handling. It is necessary that there be reliable identification procedures of all shellstock so as to further combat the harvesting of shellfish from noncertified waters.

\section{Improved Coordination of Research and Inspection Methods}

The cost of research in food processing is increasingly expensive. There is not only the necessity to develop new products to expand oyster products, but also to improve present products and develop methods to meet FPA effluent guidelines. Due to the high cost of research and inspection efforts, it is essential that sufficient planning and coordination occur to more sharply focus the expenditure of funds and personnel for problem resolution. Another 
aspect of this particular issue is that it is essential that public health research results are translated into inspection tools that can be used by plant inspectors. At the Federal level, there are no formal mechanisms established to ensure coordination of research and services.

\section{Increased Inspector Training}

More and more inspectors are being recruited from urban areas of the country who have less personal knowledge of water-related activities. One common complaint voiced throughout the interviews was that both State and Federal inspectors are not knowledgeable in other agencies' requirements relating to oyster activities. 


\section{MARKETING AND CONSUMPTION}

Most of the issues related to marketing and consumption of oyster products are primarily socio-economic in nature; nonetheless, the review uncovered several issues which fitted into the matrix design of this report.

\section{A. Technica1 Issues}

\section{Insufficient Product Development}

Development of new product forms to expand the market for oysters is almost nonexistent. The consumption of traditional oyster products is static or declining; and the industry does not have funds or expertise necessary to engage in the costly process of product development. For marketing purposes, a wider variety of products would be beneficial.

\section{Retail Quality Standards}

Only a token attempt has been made at the retail level to develop quality standards for oysters. It has been reported that due to the wide variations in product quality, many consumers are reluctant to purchase fresh oysters. Excessive drip loss would be one example of such product quality variance. A lack of such standards for retail products can weaken confidence in oyster products. It has been reported that last year was one of economic hard times for the industry; and, therefore, free liquor contents of 40 percent were found in the marketplace, well above the customary limit of around 15 percent. Uniform product standards are needed to protect the consumer and honest packer from economic fraud through excessive watering of products.

\section{Consumer Education}

Consumers should be made more aware of the attributes of good product quality. This probably holds true for all seafood products, but oysters in particular. Many persons believe that consumers are ignorant of all of the control measures involved in purveying acceptable products and that only "certified" oyster from approved oysters beds should be purchased to the exclusion of a11 others.

\section{Retailer Training}

There is a general need for increased training at the retail level for all seafood products. Most often, seafood products, including oysters, are found in the meat section of supermarkets, and personnel working in such sections are usually more trained in meat and poultry products. It has been the experience of some persons interviewed, as well as the task group conducting the review, to observe retail display of shucked oysters displayed without sufficient refrigeration, resulting in extreme quality loss for the product.

\section{B. Socio-Economic Issues}

Per capita consumption of oysters in the United States has been steadily decreasing for several decades. The projected outlook for future consumption does not indicate a reversal of this trend. 
A 1969 consumer panel study on shellfish consumption reported that (1) the per capita consumption of oysters declines as per capita income rises, (2) oysters are primarily consumed by older age groups and (3) consumption of oysters in restaurants and institutions is substantially less than in private homes.

While these findings may have been indicative of consumption patterns in the late 1960 's, the above description is not necessarily true of today's consumers. For example, during the course of this review, restaurateurs expressed the opinion that consumption is not limited to any age or income groups; and wholesalers indicated that a substantial portion of sales have been to the institutional buyers. The seasonality of fresh oyster products is also a major factor in consumption habits. The lack of frozen and packaged product forms intensifies this seasonality and curtails a year-round market. Industry sources feel that oysters have acquired a poor product image among consumers. The fresh product form, which accounts for most of the retail and institutional sales, is a raw, viscous product with the viscera still intact. In addition to the alleged offensiveness of the raw product to potential consumers, oysters have the stigma of having been grown in or near polluted waters. This is particularly true for "restrictive waters," i.e., those which are opened and closed depending on the pollution indicator levels.

\section{Marketing}

As previously discussed, oysters are marketed mainly in fresh product form. The necessity of developing and promoting new product forms is recognized. However, the limited financial resources of this small industry have seriously hindered both technological research and promotional campaigns. The overall lack of advertising and promotion has placed oysters at a competitive disadvantage with seafood and other food products. The lack of consumer demand coupled with the high losses due to perishabilities make food store and restaurant proprietors hesitant to market fresh oyster products. Therefore, when retailers do market this product, a high mark-up is required. Due to handling difficulties and spoilage costs associated with fresh oysters, some retail outlets have reportedly developed a preference for the canned product.

Therefore, any efforts to increase the supply of oysters must be complemented with advertising and marketing programs. The potential exists for development of packaged product forms to receive consumer acceptance. In order to finance the needed programs, the oyster industry should take advantage of legislation, such as the Agricultural Marketing Agreement Act, which allows for the creation of marketing orders and agreements. Essentially, these orders and agreements call for a joint industry effort in marketing and supply control, in promotion, and in research.

\section{Politica1 Issues}

\section{None Identified}

During the conduct of the industry review, no political issues were identified for this particular section of the paper. 


\section{Institutional Issues}

\section{Consumer Education}

Few states have a specific seafood marketing program, like those in Maryland and Florida, to promote the sale of oysters and other seafoods. A state/industry cooperative program to promote oyster sales by researching and developing new marketing areas, preparing feature materials for food editors, promoting new products, and placing out-of-state buyers in touch with local processors can help overcome sales inefficiencies in domestic and foreign markets.

\section{E. Public Health Issues}

As was indicated in introducing public health aspects of the various levels of oyster production, the ultimate goal is to provide the consumer with a safe, wholesome product. It is in the marketing and consumption of oysters that the culmination of efforts of proper or improper growing, harvesting, processing, shipping, and in marketing occur. The safety and quality of the product in whatever form consumed will determine the continued existence of the industry.

\section{Retai1 Standards}

Quality standards for oyster products should not cease with the processor. Spoilage and deterioration can occur at the retail level particularly with the infrequent inspection of trucks and stores. In retailing oysters there should be requirements that raw oysters be maintained at appropriate temperatures. The $\mathrm{pH}$ of random samples should be taken periodically as an index of spoilage. Surveys should be made to determine the numbers and types of bacteria found in market products and results related to spoilage and public health hazards.

The control of problems at the retail level ultimately depends on whether adequate sanctions are placed on business. The responsibility and liability of retailers for failure to maintain oyster products in a wholesome state should begin upon taking possession of the product.

If oysters and oyster products are monitored at every stage from harvesting through processing to the consumer, then the causes of problems can be assessed more accurately, and liability more equitably assigned.

\section{Stringent Raw Material Requirements for Canned Oysters}

Harvesting of molluscan shellfish for canning in the U.S. is limited to those waters which have been certified as safe for $r$ aw consumption. By contrast, the water quality and origin of canned oysters imported into the U.S. can be only minimally addressed due to technical and jurisdictional limitations. Foreign trade policies, therefore, may discriminate against domestic oyster production by allowing less stringent standards for imports. Domestic public health policies prohibit the harvest and heat processing of oysters with mildly elevated coliforms even though the product is rendered "safe" through commercial sterilization. This possible double standard places domestic canned oyster production at an economic disadvantage. 


\section{FINDINGS AND CONCLUSIONS}

\section{A. Findings}

As can be seen from this report, there are a number of similar issues which occur in each of the previously defined industry segments. As such, these similarities factor out and emerge as principal issues. There are additional issues that while they do not confront each industry segment, are of sufficient import to also need resolution for the continued economic viability of the U.S. oyster industry. The following is a listing, in no particular priority, of the principal issues identified during the conduct of this review of the U.S. oyster industry:

o Competition For Use of Growing Waters and Adjacent Land

- Multijurisdictional Authorities and Regulations

- Decreasing Resource Base

- Industry Revitalization

- Social Concerns

o Industry Has Little Influence on Public Decision-Making

- Precision of Microbiological and Chemical Standards Currently Employed in Classifying Suitable Growing Waters and Final Products

- Research and Services Coordination

Each of these issues are discussed further.

\section{Principal Issues}

\section{a. Competition for Use of Growing Waters and Adjacent Land}

Competing uses of the coastal zone (such as urban development, heavy industry, recreational development, etc.) are among the root causes for many of the problems of the oyster industry. It is reasonable to assume that the increasing trend of competing uses will continue, and probably escalate, particularly for recreational usage. Due to the small size of the oyster industry, and the lack of public awareness and imprecise conventional methods of economic measurement, the oyster industry does poorly in economic benefit/ costs studies when compared to other industries.

Since the oyster requires the highest quality water to meet standards necessary for safe human consumption, decreasing water quality in many areas has significantly decreased the supply of the harvestable resource. Because of high adjacent land values, many processors have found it difficult to expand facilities and to obtain the necessary land for waste treatment. In this respect the oyster industry is quite similar to agriculture in its inability to compete with higher value industry where, for whatever reason, land values are significantly inflated. 
If the oyster industry is to be maintained and the resulting product is to remain available to consumers, special consideration must be given to coastal zone planning at the Federal, State, and local levels to assure that steps are taken to maintain and provide adequate growing areas for production of oysters.

\section{b. Multijurisdictional Authorities and Regulations}

The industry is regulated by a number of Federal, State, and local authorities, each of which has its own requirements to which industry must comply. At the State level, growing water responsibilities are usually divided among health agencies, conservation agencies, air and water pollution agencies, universities, and research and development agencies. At the Federal level, regulatory and inspection responsibilities are shared by NMFS, FDA, EPA, OSHA, and the Corps of Engineers.

Because of the number of agencies directly involved, there is substantial duplication which results in excessive record keeping, visitations, and general cost to the industry. The varying orientation and objectives of the differing agencies result in a certain amount of confusion. At the extreme, there can be conflicts between regulations of agencles which produce a hardship on the industry. Tax regulations differ among food industries, sometimes placing oyster processors at an economic disadvantage.

Additionally, there are a number of other governmental bodies whose decisions indirectly impact upon the oyster industry. Local county agricultural committees and urban drainage authorities, local public works bodies, regional and multi-state river basin commissions, and zoning authorities are just a few examples of public entities whose policles and programs affect the future of the oyster industry.

Serious consideration should be given to reducing duplication and multijurisdiction by consolidating authority into fewer agencies. At a minimum, a leglslative review should be undertaken to study the duplication of acts and programs with a view toward consolidation or to provide a better method of coordination of multi-agency activities.

\section{c. Decreasing Resource Base}

U.S. oyster production has been decreasing for many years. Current production is about one-third of that of the early 1900's. Many areas which formerly produced oysters are no longer suitable because of domestic or industrial pollution, natural disaster, oyster diseases, and predation. Seed supplies from natural reproduction have also decreased in many places because water quality has become unsuitable for larvae and juveniles. It is estimated that the harvestable resource base is reduced by 0.6 percent water acres annually. Mass mortalities through disease epidemics have decreased production in the Chesapeake Bay, Delaware Bay, and the Gulf of Mexico. It is further believed that overharvesting in earlier years accounted for much of the depletion of the resource. Probably the best that can be expected is to arrest the present trend of declining production from natural stocks. In the long run, depending on public policy, some areas now closed because of pollution may be restored. 
Aquaculture as broadly defined can increase oyster production on public and private bottoms. Currently, 40 percent, or 20 million pounds, of U.S. oyster production comes from aquaculture. Technology in private oyster farming is well-known, and coupled with methods used in other parts of the world, such aquaculture could vastly increase U.S. production. Though suitable space for aquaculture of oysters has decreased, there remain sufficient areas for increasing production given adequate markets and profitability. It is conservatively estimated that U.S. production could be increased from the 1972 level of 20 million pounds to at least 35 million pounds and as much as 80 million pounds by 1985. A substantial effort would be needed to coordinate a number of programs for this estimate to become a reality.

\section{d. Industry Revitalization}

With the exception of a few large commercial operations, the character of the oyster industry has remained virtually unchanged for generations. Seeding, growing, and conservation of the resource is primarily a public responsibility in most States. Harvesting is done largely by individuals or family groups, oftentimes with inefficient gear as required by State or local regulations either for conservation or social purposes. Many processing facilities are small, family-owned, labor-intensive, and marginallyprofitable. Marketing of oysters has been confined to the fresh, canned, and frozen items. There has been little new product development.

Faced with a series of issues, primarily external such as resource depletion, competition for growing water areas, and new regulations--the industry, as well as Government, must look at revitalization needs if the industry is to be reasonably competitive and economically viable.

\section{e. Social Concerns}

Much has been written about the social independence of watermen and their resistance to change a unique lifestyle despite lower incomes often associated with that choice. Whether such may be legend, or fact, social concerns have historically played a major role in legislative decisions made at a11 levels of Government.

Private leasing versus public waters is an excellent case in point. Resource availability and economic value are higher on privately cultivated beds than public reefs. Normally, this would dictate an industry trend toward private leasing. In some major oyster-producing areas, however, nearly all production comes from public reefs, and there appears to be no movement toward private leasing. Social implications are generally given as the reason. Individual watermen who harvest the bulk of the oysters do not have, nor can they readily acquire, the knowledge, expertise, and the financial support to profitably engage in oyster farming. There is widespread concern among watermen that increased private leasing would cause substantial displacement of fishermen. 
Gear restrictions and catch quotas in many areas are imposed to satisfy social as well as conservation needs. Again, there is real concern that a more efficient and economic method would create job displacement. Although a significant part of the labor force in the oyster industry has been sometimes characterized as old, and marginally employed, there appears to be increased recruitment of younger people into the harvesting sector of the industry who are apparently choosing the "quality of life" of the waterman.

\section{f. Industry Has Little Influence on Public Decision Making}

Although there are associations representing harvesters and processors from the local to the national level, almost without exception, individuals in the industry constantly voice the complaint that they have little influence with public bodies. Unfortunately, there is diversity of opinion on many issues within the total industry, and thus it is difficult to develop a united position except for major issues. The total industry is composed of small units and oftentimes does not possess the capital to promote its image or to adequately present its views in an organized format.

g. Precision of Microbiological and Chemical Standards Currently Employed in Classifying Suitable Growing Waters and Final Products

The overwhelming consensus of those interviewed was that the current system employing indicator microorganisms for classifying growing waters, when used in conjunction with sanitary shoreline surveys and other control procedures, was sufficient for consumer protection. However, several areas were singled out which could benefit from further technical and scientific refinement. One area dealt with a need for more precise evaluation of public health significance of indicator microorganisms. There is an expressed opinion that current microbiological limits need further study and refinement. The current standards may be too discriminating. Should such prove to be the case, less restrictive standards would have economic consequences.

As more oysters would be available for utilization, there would be less of what many perceive to be economic discrimination against the U.S. oyster industry. The latter seems to be particularly the case in the instance of canned oysters when, by U.S. inspection policy, raw material for canning must meet the same growing water microbial quality standards as products destined for raw consumption. There is concern that for canned products, such stringent raw material requirements are not necessary from either a public health or quality standpoint. Additionally, there are extreme technical and jurisdictional limitations in ensuring that foreign imports of canned oysters meet similar stringent growing water raw material microbiological requirements.

Additionally for microbiological and chemical standards, there is a need to develop more rapid and real-time remote monitoring systems. The feasibility of technology transfer of NASA-developed remote analysis and monitoring with transmission systems of biological information through telemetry for use on buoys, should be investigated for possible development and use by States in classifying growing waters. Aside from the current indicator micro- 
organisms used to classify growing waters, many Government officials and industry members alike voiced a need to develop rapid and economical isolation and identification techniques for the hepatitis virus so further studies could be undertaken to determine the significance of indicator systems and specific viral presence.

In the area of chemical standards, there was a preponderance of opinion for a need to determine the logical rationale for such standards and to sufficiently fund specific research programs to begin developing standards as opposed to the current procedure which many perceive to be accomplished only in "crisis" situations.

\section{h. Research and Services Coordination}

Difficulties in coordination are due in part to the numerous multijurisdictional authorities which impact on the oyster industry. There is some concern that many research or service activities are either underfunded or understaffed resulting in a subcritical mass of resources necessary to achieve their intended purpose.

With the multiplicity of agencies and specific budgets to provide assistance to the oyster industry, more planning and coordination are needed to focus on problem resolution.

\section{B. Conclusions}

The two principal conclusions to this report are the need to revitalize the industry and a need for leadership in developing a revitalization program.

\section{Industry Revitalization Needs}

The serious problems facing the industry--resource depletion, competition for and pollution of growing water, lack of mechanization, biological hazards and the absence of unified public direction, require that Government must assume leadership in making it possible for the industry to revitalize itself and become more economically viable.

The following needs for revitalizing the U.S. oyster industry are identified from the survey of people who are themselves personally involved in the industry.

\section{a. Pollution Abar $\cong$ ment}

A substantial increase in Federal, State, local and private efforts toward the abatement and control of water pollution are basic to the survival of the oyster industry, otherwise continued decline is inevitable. If the oyster industry is to be maintained, consideration must be given to coastal zone planning at the Federal, State, and local levels to ensure that steps are taken to provide and maintain growing waters and suitable areas for harvests.

One of the more technical obstacles facing the industry is the 1ongstanding need for a quick, reliable method for identifying hepatitis virus in 
oyster growing waters, so that public health can be protected without closing the oyster beds unnecessarily.

Buffer zones should recognize new fail-safe factors incorporated in modern sewage plant facilities. Since oysters are commercially sterilized during the canning process, specific additional review with state control agencies should be undertaken to determine if regulations could be changed which while allowing for appropriate enforcement procedures, permit the canning of oysters from waters containing slightly elevated coliforms.

Public health significance of indicator microorganisms needs to be more specifically defined. The application of remote but on-site sampling and analysis techniques should be investigated for enforcement purposes and radar surveillance should be considered for use on growing waters to prevent illegal harvesting.

\section{b. Expanding Natural Production}

Oyster growing bottoms that have been destroyed should be brought back into production, their areas expanded, and their productivity increased. Beds victimized by natural disaster, silting, predators, and disease can be rehabitated. Those that are depleted can be seeded to augment production, but standards are needed to ensure that seed stock is free from disease, pests, and predators. Genetic research is needed to develop new strains that are fast growing and more resistant to disease. Methods also should be developed to control oyster predators.

\section{c. Aquaculture}

U.S. oyster production could be greatly increased through aquaculture. There is less regulation of private beds, and it is in the personal interest of the operator to practice conservation, increase productivity, and maximize efficiency of operations. Oystermen could be encouraged to go into aquaculture with easier credit.

\section{d. Mechanization}

If the oyster industry is to grow and prosper it must become more mechanized in some industry segments. Dredges are available that can harvest oysters efficiently without undue damage to the beds, but there is a critical need to develop automatic equipment for sorting, and shucking oysters. The weakest link in the chain is shucking, which is a dying art, forced out of existence because young people are unwilling to endure the tedium, uncertainty, and low wages that often characterize the job. A mechanical shucker should be developed that can overcome the obstacles of rough, irregular, and clustered shells without damaging the delicate mollusk or degrading its quality.

\section{e. New Product Development}

The oyster industry is losing ground as a competitor in the U.S. food market. Much of its output is sold in forms unpalatable to large segments of the population, and unfavorable publicity worsens the problem. New, attractive 
and delicious product forms could greatly expand the market. These efforts must be preceded by market research to determine the kinds of products that would attract buyers such as fast food service operations.

\section{f. Advertising and Marketing}

In order to increase advertising and marketing programs, the oyster industry should take advantage of legislation, such as the Agricultural Marketing Agreement Act, which allows for the creation of marketing orders and agreements. These call for a joint industry effort in marketing and supply control, promotion, and research.

\section{g. Financial Assistance}

Credit must be available for small, independent operators to meet new regulations and improve and modernize facilities. Since the typical oyster harvester, and processor have limited collateral, Government must establish some sort of improved program for backing loans.

\section{h. Multijurisdictional Authorities and Regulations}

Jurisdiction should be consolidated into fewer agencies: multijurisdiction between agencies should be reduced to the minimum; and coordination between agencies should be improved.

Regulations should be written in simple, direct language; interagency conflicts should be reduced and compliance procedures should be simplified. Reciprocal agreements between Federa1, State, county, and local authorities responsible for pollution control and sanitation standards could reduce the number of inspectors and improve efficiency.

\section{i. Research Coordination}

Large programs of research and assistance are being carried out by various Federal and State agencies and universities. But there is no central mechanism to establish requirements and priorities, plan píojects, assign resources of funds, talent, and facilities, coordinate efforts, monitor progress, and implement results. Until such a mechanism is established, duplication and inefficiency of the research effort will delay solutions to the critical issues that hamstring the industry.

\section{j. Social Concerns}

Oystering is one of the last holdouts of rugged individualism in America. The life is hard, the pay uncertain, but men continue to follow it because of the tradition that belongs to the trade, the feeling of freedom and independence, and the enjoyment of boats, water, and the outdoor life that most people are able to satisfy only infrequently as recreation. Regulations that govern the industry should take into account the premise that it is a worthwhile investment for society to preserve such a way of life, not only for the participants, but for the rest of the population. 


\section{Leadership Needs}

For the oyster industry, there is a need to establish realistic unified goals; to determine needs and priorities for research and development, monitor its progress, and implement the results. Further there is a need to eliminate duplication, cross purposes, confusion, and inefficiency in regulations, and among regulatory agencies. It is unlikely that the oyster industry by itself can deal effectively with these matters. A small, dynamic Government/industry commission or task force, formed of knowledgeable people dedicated to serving the fublic in this matter, might do the job. 


\section{REFERENCES}

Council on Environmental Quality. 1975. Its Sixth annual report. Washington, D.C., 763 p.

Dresse1, D. 1976. Personal communication.

Environmental Protection Agency, Office of Enforcement. 1975. National shellfish register of classified estuarine waters 1974 . Its

Publication No. EPA-330/1-75-002, 25 p.

Gosselink, J.G., E.P. Odum, and R.M. Pope. 1974. The value of the tidal marsh. Louisiana State University Sea Grant 74-03, 25 p.

Kelly, C.B. 1971. The health hazards associated with the consumption of shellfish from polluted waters. Environmental Protection Agency, Division of Water Hygiene, 21 p.

MacMillan, R.B. and W. Eisele. 1975. Joint resolution. Proceedings 9th National She11fish Sanitation Workshop, June 25-26, p. 75.

Marasco, R.J. 1973. An appraisal of the alternative earning power of the Maryland oystermen. National Shellfisheries Assocation, 1972 Proceedings, 63:48-52.

Maryland Department of Economic and Community Development. 1976. Growth prospect for the oyster industry in Maryland. Annapolis, Md., p. 31.

Maryland Department of Natural Resources. 1976. Interview with M. Paparella, July $17, \cdot 1976$. Oxford, Md.

Miller, M.M., and D.A. Nash. 1971. Regional and other related aspects of shellfish consumption. Some preliminary findings from the 1969 consumer panel survey. National Marine Fisheries Service, Circ. 361, p. 3-4, 9-13.

National Commission on Water Quality. 1976. Report to the Congress, March 18. Washington, D.C., p. 26-27.

National Marine Fisheries Service. Grand-in-aid for fisheries, program activities. Various issues.

National Marine Fisheries Service, Economic Research Division. 1974. Basic economic indicators, oysters 1947-73. Its current Fisheries Statistics No. 6273,43 p.

National Oceanic and Atmospheric Administration. 1976. NOAA aquaculture plan. Prepared by National Marine Fisheris Service and Office of Sea Grant, 142 p., Manuscript. 
New York State Department of Environmental Conservation and New York Sea Grant Institute. 1975. Workshop proceedings of the shellfish management program. Stony Brook, N.Y., July 1975, p. 49.

Public Health Service, Division of Environmental Engineering and Food Protection, 1965 revision. Part 1 . Sanitation of shellfish growing areas. Washington, D.C., 32 p.

Rockwood, C. 1973. A management program for the oyster resource in Apalachicola, Florida. Florida State University, Tallahassee, Fla., p. 143.

Sokoloski, A., T. Gaucher, A. Koers, and R. Kelly. 1973. The Atlantic oyster fishery. University of Rhode Island, Kingston, R.I., p. 33.

Tweeter, L. 1970. Foundations of farm policy. University of Nebraska Press, Lincoln, Neb., pp. 171-176.

U.S. Department of Commerce, Bureau of the Census. 1974. Statistical abstract of the United States. Washington, D.C., p. 9, 177.

U.S. Department of Commerce. 1976. A marine fisheries program for the nation. Table 4. Washington, D.C., p. 69.

Vaughn, C.L. 1973. National survey of the oyster industry's problems. Prepared for National Marine Fisheries Service, Contract No. $\mathrm{N}-043-41-72, \mathrm{p} .23$.

Wheaton; F.W. 1971. Engineering approach to oyster processing. Transactions of the American Society of Agricultural Engineers, $14(1): 187-192$. 




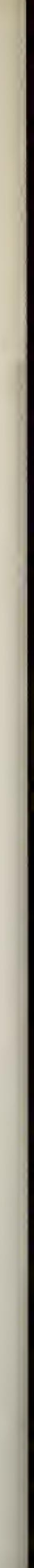





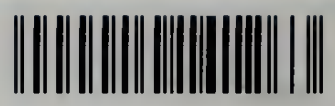 \\ A000014141263}

NOAA--S/T 77-2758 